\title{
Article \\ STEAM Project-Based Learning Activities at the Science Museum as an Effective Training for Future Chemistry Teachers
}

\author{
Valentina Domenici (D
}

check for updates

Citation: Domenici, V. STEAM Project-Based Learning Activities at the Science Museum as an Effective Training for Future Chemistry Teachers. Educ. Sci. 2022, 12, 30. https://doi.org/10.3390/ educsci12010030

Academic Editor: James Albright

Received: 15 November 2021

Accepted: 28 December 2021

Published: 6 January 2022

Publisher's Note: MDPI stays neutral with regard to jurisdictional claims in published maps and institutional affiliations.

Copyright: (C) 2022 by the author. Licensee MDPI, Basel, Switzerland. This article is an open access article distributed under the terms and conditions of the Creative Commons Attribution (CC BY) license (https:// creativecommons.org/licenses/by/ $4.0 /)$.
Dipartimento di Chimica e Chimica Industriale, Università di Pisa, 56124 Pisa, Italy; valentina.domenici@unipi.it

\begin{abstract}
Non-formal learning environments, such as science museums, have a fundamental role in science education and high potentialities as ideal contexts for science teachers' training. These aspects have been analyzed and reported in several recent works mainly focused on students' perception of science and increased engagement towards scientific disciplines. In this work, a project-based learning methodology optimized and experimented in the frame of a pre-service chemistry teachers' course at the University of Pisa (Italy), during the last eight years, involving in total 171 participants, is presented. This educational project has several distinctive features related to the STEAM philosophy, with a high level of multi-disciplinarity and creativity. Most of the laboratories and chemistry-centered activities were conceived, planned and carried out by the future chemistry teachers in non-formal contexts, such as science museums. A case study based on a series of non-formal laboratories designed by a group of students during their training in the academic year 2018-2019 and performed in a science museum is reported and examined in details. In this paper, all steps of the STEAM project-based learning methodology are described underlining the main learning outcomes and cognitive levels involved in each step and the relevant methodologies proposed during the training course and adopted in the project. The effectiveness of this pre-service teachers' training methodology is finally discussed in terms of participants' motivation and interest towards the course's content, students' final judgment of their training experiences and, in particular, of the STEAM project-based learning activities. From the students' feedbacks and final assessment, the role of the non-formal context in teaching and learning chemistry and the efficacy of developing educational activities related to current and real-life chemistry-centered topics emerged as very positive aspects of the proposed approach.
\end{abstract}

Keywords: chemistry education; STEM; STEAM; non-formal environment; science museum; PjBL; interactive learning; project-based learning; teacher training

\section{Introduction}

The role of non-formal contexts in learning and teaching [1-8] became a crucial aspect in science education $[9,10]$. In the recent years, out-of-school programs and outreach activities [11-19] designed for children, school students and adults concerning chemistry and STEM (Sciences, Technology, Engineering and Mathematics) disciplines [20] have been reported and discussed in terms of learning outcomes, effectiveness of the non-formal contexts and acquired skills. Among non-formal environments, science museums [21,22], and, in particular, museums of chemistry, collections of chemical instruments and historical scientific collections demonstrated to influence positively the learning of chemical concepts, to enhance the engagement of different publics into chemistry and to motivate high school students in continuing their studies in science and in chemistry [23-32]. Chemistry is recognized from the scientific community as a 'central science', since it connects different disciplines such as biology and medicine, nanoscience and material science [33], however, the general public perception of chemistry is not always positive and the general attitude of students toward chemistry is very much influenced by their experiences at school [34-36]. The evidence of a connection between the formal and traditional teaching of chemistry and 
the perception of chemistry as 'abstract', 'difficult' and 'far from everyday life' [35,36] is one of the reasons of a rethinking of the chemistry teaching. In this respect, the training of pre-service chemistry teachers is an important issue [37]. Few investigations focused on methodological aspects relevant in chemistry education and innovative approaches to train pre-service and in-service teachers in chemistry, such as the STEM teaching philosophy [20] and non-formal teaching methods, have been published so far.

In this paper, a teaching strategy optimized and tested in the last decade to train future chemistry teachers in the frame of a 'Chemical Education' course at the University of Pisa [38], in Italy, is described. The adopted methodological approach is based on STEAM (STEM with the inclusion of Arts) laboratorial activities [39] developed in the context of science museums. Within this approach, undergraduate students and pre-service chemistry teachers attending the course typically follow a project-based learning (PjBL) strategy [40] to design structured laboratorial activities to be performed in out-of-school contexts, such as science museums.

The manuscript is organized as follows: Section 2 reports the theoretical background of formal/non-formal/informal learning, the role of science museums, the STEM approach and the PjBL method applied to chemistry education. Section 3 reports a description of the STEAM project-based learning methodology developed in the frame of the 'Chemical Education' course to train future chemistry teachers. Section 4 describes in detail the activities performed by a group of undergraduate students who attended the course during the academic year 2018-2019, as a case of study. In Section 5, the methodological approach used to train future chemistry teachers is discussed based on the results of the final students surveys, and from the feedbacks collected during and after the activities in the non-formal contexts. Conclusions are summarized in Section 6.

In this work, the usefulness and effectiveness of the STEAM project-based learning method in preparing future teachers in chemistry and in stimulating their reflections about learning and teaching chemistry in non-formal contexts is discussed. Moreover, the role of designing laboratorial activities where chemistry is presented in connection with real everyday-life problems, and other disciplines, either scientific or humanistic ones, emerged as a very positive aspect from students' feedbacks.

\section{Background}

\subsection{Formal, Non-Formal and Informal Learning}

The role of context in learning processes has been investigated at many levels, both theoretical and experimental ones [1]. The definition itself of 'context of learning' is not rigid, and probably not so unique, as recently reported in a concept-paper by Dohn et al. [2]. On the other hand, the contextual analysis in students learning has a long tradition, starting from the major contributor of the 'activism', John Dewey, to the fundamental studies by two founders of 'constructivism', Jean Piaget and Lev Vygotsky, who explored the role of social and cultural contexts in cognitive development [2]. A general accepted classification of contexts of learning bases on the distinction among formal, non-formal and informal learnings, whose definitions can be summarized as [3-6]:

- Formal Learning: also called 'scholastic learning', typical of schools, universities and recognized institutions, it is associated to a certification/degree. It can also be applied to professional learning in private or public contexts, such as the professional continuous training finalized to job qualifications and progression.

- $\quad$ Non-Formal Learning: it is normally planned and it takes place apart from the schools and other formal institutions. It is typical of museums, cultural centers, voluntary associations, sports or arts associations and so on. Usually, it is not associated to a certification; it can involve both adults and children. Non-formal learning is, in general, a conscious learning.

- Informal Learning: it consists of experiences and actually living in the community and in the family. Informal learning can be unconscious; it has no age limits, since it happens during the whole life. 
Such definitions, even though not-exhaustive, have been included in the European policies of education since $1996[3,6]$ in connection with the 'lifelong learning', the continuous process where individuals learn and acquire new competences, skills and knowledges during the whole life, animated by different aims and stimulus, in different contexts and in different ways [4].

Taking into account the distinctions among formal, non-formal and informal learning, different contexts of learning can be characterized. A context of learning can be characterized by means of specific features, such as: (i) the physical environment or location (i.e., the school, the museum, ... ), (ii) the functions or otherwise called tasks (i.e., educational, professional, emotional, ... ), (iii) the adopted methodologies and, where it applies, the educational and teaching strategies (i.e., cooperative, laboratorial, ... ), (iv) the specific targets (i.e., students, children, adults, ... ) and (v) the cultural/historical and social aspects (i.e., in the city, in the periphery, in the modern age, ... ).

\subsection{Non-Formal Learning and Chemical Education}

Focusing into the learning and teaching of chemistry, in the last decades non-formal and informal learning and teaching emerged as crucial aspects in education of both children and adults [10]. Several studies [11-19,21-32] have indeed evidenced the role of out-ofschool activities in motivating students and promoting positive attitudes toward chemistry [15], testing new teaching and learning methods applied to chemistry $[14,16,18,40]$, dealing with new and emerging topics in chemistry, such as sustainability and green chemistry [11-14], as well as problematic themes, such as environmental pollutions and microplastics [24,28,32]. Among various possibilities, informal activities, such as the individual visit to a museum or an open day, or the consumption of a TV show may influence positively the learning of specific chemical topics. Non-formal learning activities, which are usually more structured and connected with school programs and chemistry curricula, have been the object of deep researches in chemistry education. Examples of successful experimentations of non-formal laboratorial activities, called Schülerlabor, have been reported in Germany by Eilks and collaborators [11-14]: they have elaborated a differentiated learning approach by exploiting the typical features of non-formal environments, developed and tested on the topic of sustainability. Remarkably, these non-formal laboratorial activities showed to be effective in including low-achievers and students with different abilities [11]. Known experiences of non-formal activities centered on chemistry, whose impact on students have been reported [15-19,29-32,41], are the so-called outreach programs, where universities and other institutions organize laboratories and other activities for kids and for school students. In the last years, several examples of remote laboratories and virtual highly interactive platforms have also been developed to inspire interest about chemistry and scientific research and to orient students in continuing their studies in science and chemistry, too [15,31,41-44].

Even though non-formal learning activities can be performed in the school context, typically non-formal learning activities and methods have been incremented in out-ofschool contexts. Typical non-formal contexts relevant in chemistry education are the science museums, or specifically the museums and collections of chemistry [21-23,26,27], and the science festivals $[30,31,45]$.

\subsection{The Role of Science Museums in Chemical Education}

Science museums with sections devoted to chemistry as well as museums and collections of chemistry represent typical non-formal environments, whose educational role has been object of several investigations. In fact, in addition to the undoubted historical, conservative and cultural role of collections of scientific instruments, glassware, reagents and other documents relevant in chemical history [27,44,46-48], science museum and science centers are ideal contexts for designing and implementing innovative laboratorial activities $[21-23,26,49,50]$. They can offer to schools' students a space, generally more equipped with respect to the laboratories of schools, where to learn chemistry in relation- 
ships with real life and society [21-24,27,51]. Very often science museums host courses to train pre-service and in-service science teachers [18,22,23,51-54] and, in the case of chemistry teachers, the possibility to put innovative practical laboratorial activities into practice represent an added value to their training [37]. Several works have been published about the efficacy of non-formal activities developed in science museums in learning chemical and physical concepts, such as the properties of liquids and solids, the science of colors, lights and pigments, the properties of different kinds of materials, the chemistry of food and fundamental chemical topics related to safety and human health [21-23,29,31,52,53]. Significant efforts in building up innovative exhibits related to chemistry, such as interactive laboratories to explore D.N.A. or the energy associated to chemical reactions, and digital tools to approach the history of chemistry in very interactive ways, have been reported $[27,32,49,54]$ Moreover, the cultural and social roles of museums of chemistry, as well as the historical chemical landmarks [46], are connected with their potentialities as neutral contexts to stimulate critical discussions around chemical issues with relevant ethical, economic and social implications [33,36,55].

\subsection{STEM (and STEAM) in Chemical Education}

As reported in ref. [43], science museums and science centers may have among their missions the training of science teachers and science educators. Typical laboratorial activities planned in these contexts are multidisciplinary, including creativity as a key-aspect of the educational activities. These features are central of a methodological approach called 'STEM education', which means a cross-disciplinary teaching philosophy where the four disciplines, i.e., Science, Technology, Engineering and Mathematics, are integrated [20,46,56,57]. Pedagogical features of STEM teaching approach include a student-centered learning environment, the development of key transferable skills in problem solving, the development of teamwork and communication skills [56]. The possibility to integrate these four scientific disciplines is an opportunity for students to employ the fundamental knowledge of science and mathematics in exploring technology, developing new solutions with an engineering method. A further development of STEM is the inclusion of Arts, giving rise to the STEAM teaching philosophy [39,58-62], which has the aim to encourage creative solutions, increase motivation and make science learning more attractive.

Few studies have been published so far about the STEM or STEAM teaching approach applied to chemistry education. An interesting laboratorial STEM activity has been proposed to first-years undergraduate students during an introductory chemistry course concerning biodiesels [63]. Innovative laboratories have been recently reviewed [64] about 3D-printing as a tool for teaching chemistry: at the interface among chemistry, math, physics and engineering, students can learn molecular representations, visualizing molecules in 3D, or built microfluidic devices, electrolytic cells and spectrometer devices by programming with CAD software [64]. The effectiveness of an integrated STEM approach to teach electrolysis to secondary school students has been recently investigated [65]. Other few studies concerning STEM applied to chemistry education have been published, reporting a detailed analysis of the instructional practices in a laboratory of introductory chemistry course [66] and a study of the influence of a STEM-designed course on pre-service teachers chemistry content knowledge [67]. A recent study [68] investigated the impact of a smallscale interdisciplinary infusion of non-science topics and issues, like art, history, and the humanities, into an on-line course of general chemistry on student perceptions about the connections between chemistry and other disciplines, and the real world. The integrated STEM or STEAM approach demonstrated to be effective in enhancing motivation, creativity and ability to critically discuss scientific advancements taking into account philosophical and ethical issues $[39,44,57,68]$. An additional aspect recently investigated in chemistry education is the 'system thinking' in combination with STEM approach, which aim to increase the critical thinking, the reflections on science, society and ethical implications of chemistry, and develop higher order thinking skills [69]. 


\subsection{Project-Based Learning in Chemistry and Pre-Service Training of Chemistry Teachers}

Active learning and teaching methods referring to the constructivism theory have been widely explored and applied to chemical education at different levels from the primary school to the university [40,70-77]. Chemistry is indeed a very experimental discipline and the role of laboratorial activities, where students are actively involved in all steps of the learning process, has been recognized as a central aspect of chemistry education $[12,18,63,66,78-80]$. Despite different types of laboratorial strategies have been developed to teach chemistry, including many examples of virtual and digital laboratorial activities performed during COVID-19 pandemic [81,82], almost all recent works focus on inquiry-based, problem solving and project-based learning methods $[63,72-77,83]$. ProjectBased Learning ( $\mathrm{PjBL}$ ) is a teaching/ learning pedagogy that centers learning experiences around projects, which can be structured in different ways depending on the targets, aims and chemical contents. In chemical education, $\mathrm{PjBL}$ is used to focus on the application of chemical knowledge, developing specific abilities and skills typical of laboratorial activities, such as the use of instruments and glassware and the development of critical thinking. Moreover, chemical laboratories based on the PjBL pedagogy, usually proposed at undergraduate level $[78,80,84]$ and in pre-service teacher training courses $[83,85,86]$, aim to create a learning environment typical of the research approach. Studies on the chemistry laboratories based on PjBL show that they can promote higher order cognitive skills, students ${ }^{\prime}$ communication skills and a propensity for cooperation and teamwork $[80,84]$. Chemistry teachers' training courses, pre-service and in-service ones, are fundamental aspects, which are developed in different ways in the various countries depending on the recruitment and school systems. The inclusion of STEM philosophy and project-based learning methods in pre-service teachers' training were object of recent studies $[20,37,67,75,83,86-90]$.

\section{Methodology}

\subsection{Main Actors and Contexts of the STEAM Project-Based Learning Approach}

The main idea at the basis of the methodology used to train future chemistry teachers reported in the present work is the synergy among three main actors: the 'University', the 'Science Museum' and the 'School' (or the 'Families') (see Figure 1).

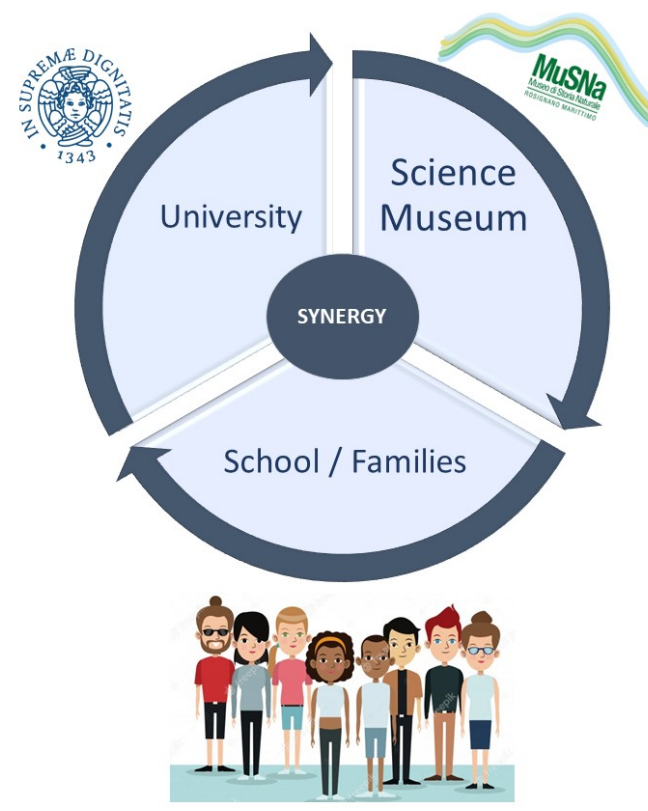

Figure 1. Representation of the synergy among University, Science Museum and School (or Families), at the basis of the STEAM project-based learning method described in this work.

The 'University' represents the context of the training course for future chemistry teachers. In the present study, the training course of 'Chemical Education', whose formal 
name is "Fundaments and methodologies for chemistry education" [38], is a 24-h optional course ( 3 credits), which is planned at the third year of undergraduate studies of the Degree in Chemistry at the Department of Chemistry and Industrial Chemistry of the University of Pisa [91]. As all other courses included in the curriculum studiorum, the course of 'Chemical Education' gives to the students a number of credits (3) and a vote (which can range between 18 to 30). The vote of each course contributes to the final vote obtained at the end of the students' career. The course of 'Chemical Education' was included in the Chemistry Degree curriculum since the 2013-2014 academic year, and it was one of the first courses on 'Chemical Education' in Italy at the university level. After the 2017-2018 academic year, an additional 24-h optional course (3 credits), named 'History of Chemistry and Chemical Education' [44], was added to the Chemistry Degree curriculum [91]. Since 2017, both courses were recognized as necessary courses for the access to the national public competition for teachers in chemistry, in the frame of the Italian law 107/2015 about the new teaching system and enrollment rules for teachers [92]. In particular, a necessary condition for new teachers to be enrolled in the public school system is the completion of 24 credits of training (called 'PF24' program), which should include 6 credits concerning teaching strategies, methodologies and discipline-centered education.

The second actor in Figure 1, namely the 'Science Museum', represents a typical nonformal learning context. As discussed in the following, the 'Science Museum' has the role to stimulate the creativity process at the basis of the design of the educational activities and laboratories. Since the 2013-2014 academic year, the 'Science Museum' was the 'Museo di Storia Naturale (MuSNa)' in Rosignano Marittimo (LI) (Tuscany, Italy) [93]. In the 2019-2020 academic year, thanks to a special project of the University of Pisa [94], the 'Science Museum' was the 'Museo Galilei' in Florence (Italy) [95]. During the academic year 2020-2021, due to the COVID-19 pandemic restrictions, the non-formal context was a virtual session of remote laboratorial activities designed by the students attending the course of 'Chemical Education'. These virtual laboratories were presented in occasion of the 'European Night of Researchers' in the frame of the 'BRIGHT' ("Brilliant Researchers Impact on Growth Health and Trust in research") project of the Department of Chemistry of the University of Pisa $[96,97]$. As detailed in the following, during these last eight years, some of the projects designed by preservice teachers were also carried out at school, during open days at the University of Pisa and in occasion of national science festivals, such as the 'Festival della Scienza' in Genova (Italy).

The third actor in Figure 1, namely 'School/Families', represents the target of the educational projects designed during the training course. In most of the cases, the STEAM project-based learning activities were planned for a specific target: primary, intermediate or high schools' students. The laboratorial activities were performed in the 'Science Museum' with students coming from specific schools accompanied by their school teachers. In some cases, these final activities were put into practice in the 'Science Museum' during open days or after-school activity programs. In these cases, the activities were open to the families and the target was more heterogenous with the presence of kids and students of different age, as in the case study reported in Section 4.

\subsection{The Partecipants of The Pre-Service Chemistry Teachers' Course}

Since the academic year 2013-2014, the number of students attending the course of 'Chemical Education' ranged between 15 to 25, as reported in Table 1 . In total, the students who attended the course were 171. Most of the students attending the course gave the final exam obtaining very good votes. The average exam vote reported for each academic year was higher than 27.75, corresponding to a 'very good' grade (note that votes can range between 18 to 30 ). 
Table 1. Number of students involved in the "Chemical Education" course during different academic years. Number of students who passed the final exam and the average exam votes are also reported. The number of students who answered to the voluntary and anonymous survey is indicated.

\begin{tabular}{ccccc}
\hline Academic Year & $\begin{array}{c}\text { Students } \\
\text { Attending the } \\
\text { Course }\end{array}$ & $\begin{array}{c}\text { Students Who } \\
\text { Took the Final } \\
\text { Exam }\end{array}$ & $\begin{array}{c}\text { Averaged Exam } \\
\text { Grade }\end{array}$ & $\begin{array}{c}\text { Students Who } \\
\text { Answered to } \\
\text { the Anonymous } \\
\text { Survey }\end{array}$ \\
\hline $2013-2014$ & 15 & 8 & $30 / 30$ & n.d. \\
$2014-2015$ & 21 & 18 & $28.56 / 30$ & 6 \\
$2015-2016$ & 21 & 20 & $28.65 / 30$ & 11 \\
$2016-2017$ & 18 & 12 & $27.75 / 30$ & 12 \\
\hline $2017-2018^{1}$ & 24 & 17 & $28.59 / 30$ & 14 \\
$2018-2019$ & 25 & 23 & $28.22 / 30$ & 14 \\
$2019-2020$ & 23 & 22 & $28.23 / 30$ & 15 \\
\hline $2020-2021$ & 24 & $18^{2}$ & $27.89 / 30^{2}$ & $19^{2}$ \\
\hline
\end{tabular}

${ }^{1}$ From this academic year, the course was included in the 'PF24' training program necessary for the access to the 'public national competitions' for chemistry teachers to be employed in the secondary schools in Italy (i.e., intermediate and high school levels) [92]. ${ }^{2}$ Some students attending the course this academic year are still involved in the final exam.

As shown in Table 1, since the academic year 2017-2018, the course was included among the courses necessary to access the 'public national competition' for chemistry teachers to be employed in the Italian secondary schools ('PF24' training program) [92]. Since then, the number of students attending the course slightly increased. Most of the attenders were students at the third or fourth year of undergraduate studies of the Degree in Chemistry curriculum. Few students (5 in total) were in-service chemistry teachers with a temporary school teacher position; few students ( 3 in total) came from different curricula then Chemistry (i.e., Pharmacy or Chemical Engineering Degree courses). In general, students attending this course were motivated and interested to the chemistry teaching course for their future job, as it was evident from the analysis of the voluntary and anonymous surveys (see Section 5). As shown in Table 1, the percentage of students answering the voluntary surveys with respect to the number of students attending the course of "Chemical Education", in the last four academic years, varies from a minimum of $56 \%(2018 / 2019)$ to a maximum of $79 \%(2020 / 2021)$. The content of the surveys will be commented in Section 5 discuss students' motivation, interest, engagement and satisfaction concerning the educational activities proposed during the course.

\subsection{The STEAM Project-Based Learning Methodology}

The STEAM project-based learning methodology was conceived at the beginning of 2013 before starting the course of 'Chemical Education' [38] and it was refined and optimized during the academic years that followed. Among the main objectives of this course, students should learn the basics of the teaching methods commonly included among the active learning strategies more effective in science education, and in particular, in chemistry education [38]. After a first introduction to constructivism theoretical background, several lessons are dedicated to the main teaching chemistry models, the rudiments of chemistry curriculum design and the role of different types of laboratorial activities in teaching chemistry at different students' levels. Among the teaching strategies presented to the future chemistry teachers, particular emphasis is given to 'problem solving', 'inquiry-based learning', 'cooperative learning' and 'concept maps' methods. These first lessons have the aim to provide the students the conceptual and the methodological instruments necessary to face up the second part of the course. According to the modified Bloom's taxonomy [98], this first part of the course aims to reach the first two cognitive levels, namely 'remember' and 'understand', with objectives that span on the first three knowledge dimensions (factual, conceptual and procedural knowledge), as reported in Table 2. 
Table 2. Objectives of the course of 'Chemical Education' during the first part of the course (white background) and the second part of the course (grey background), when the STEAM-project based learning methodology is applied. Learning objectives are organized by using the scheme proposed by Anderson et al. [98].

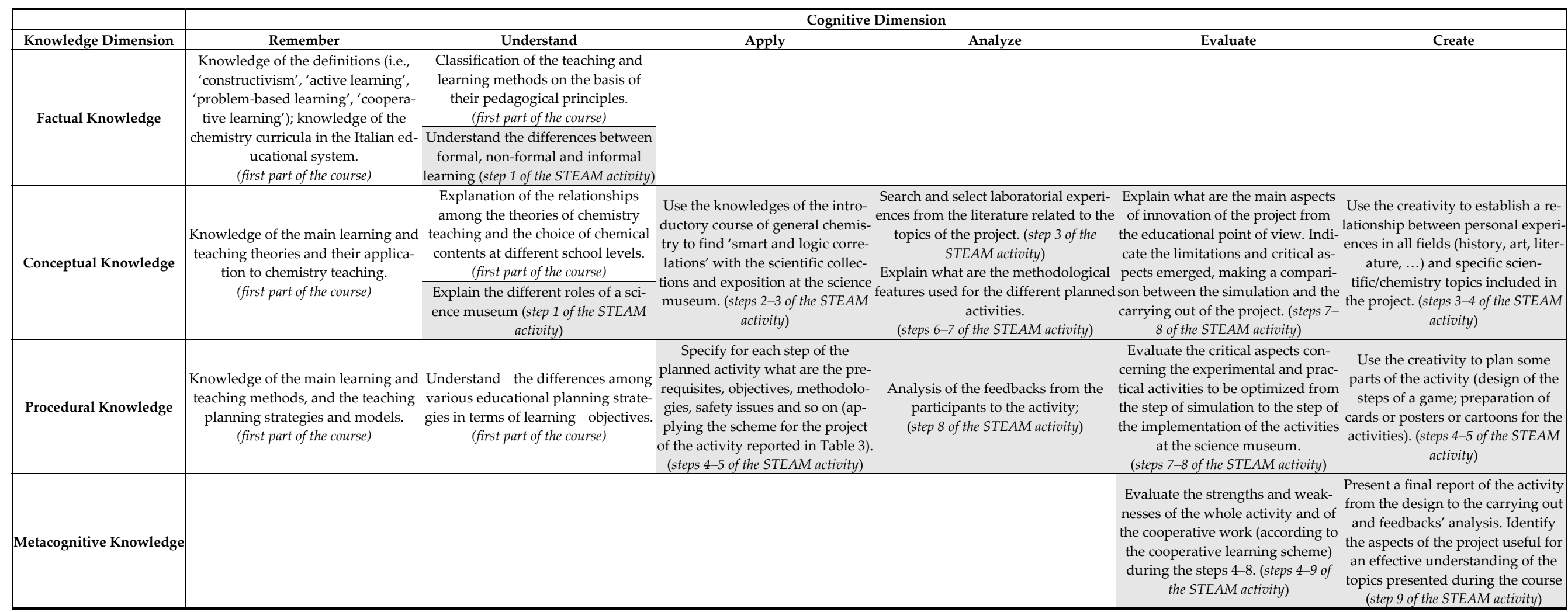


During the second part of the course, students are requested to participate more actively, not only during the lessons, but also during several extra-time activities, to collaborate with their class-mates and to interact with the teacher and eventual tutors (such as science museum animators or school teachers). The STEAM project-based learning methodology usually begin during the second part of the course of 'Chemical Education' with the visit to a science museum (step 1 in Figure 2). The visit to the museum is the occasion to introduce the role and key-features of non-formal contexts in science education. During the visit to the museum, students are invited to observe the collections or to listen the museum curators. The aim of the visit is 'to get inspired' by the place. The second step of the methodology consists of a brain-storming and a collective discussion, which can be held at the museum, after the visit, or at the University (step 2 in Figure 2). The aim of these activities is: (i) to collect students' impressions about the visit and the scientific collections or expositions; (ii) to stimulate students' thinking and creativity guided by some open questions, such as 'what are the main scientific subjects related to this collection (or exposition)?', "what chemistry topics or chemistry concepts could be related to this collection (or exposition) if any?', 'do you think that this scientific collection could be a good opportunity to teach (a scientific topic) to primary school students (or to high school students)?', 'have you seen in the museum (or in the collection) an object (or an instrument) that you would like to use for the activity?' and so on.

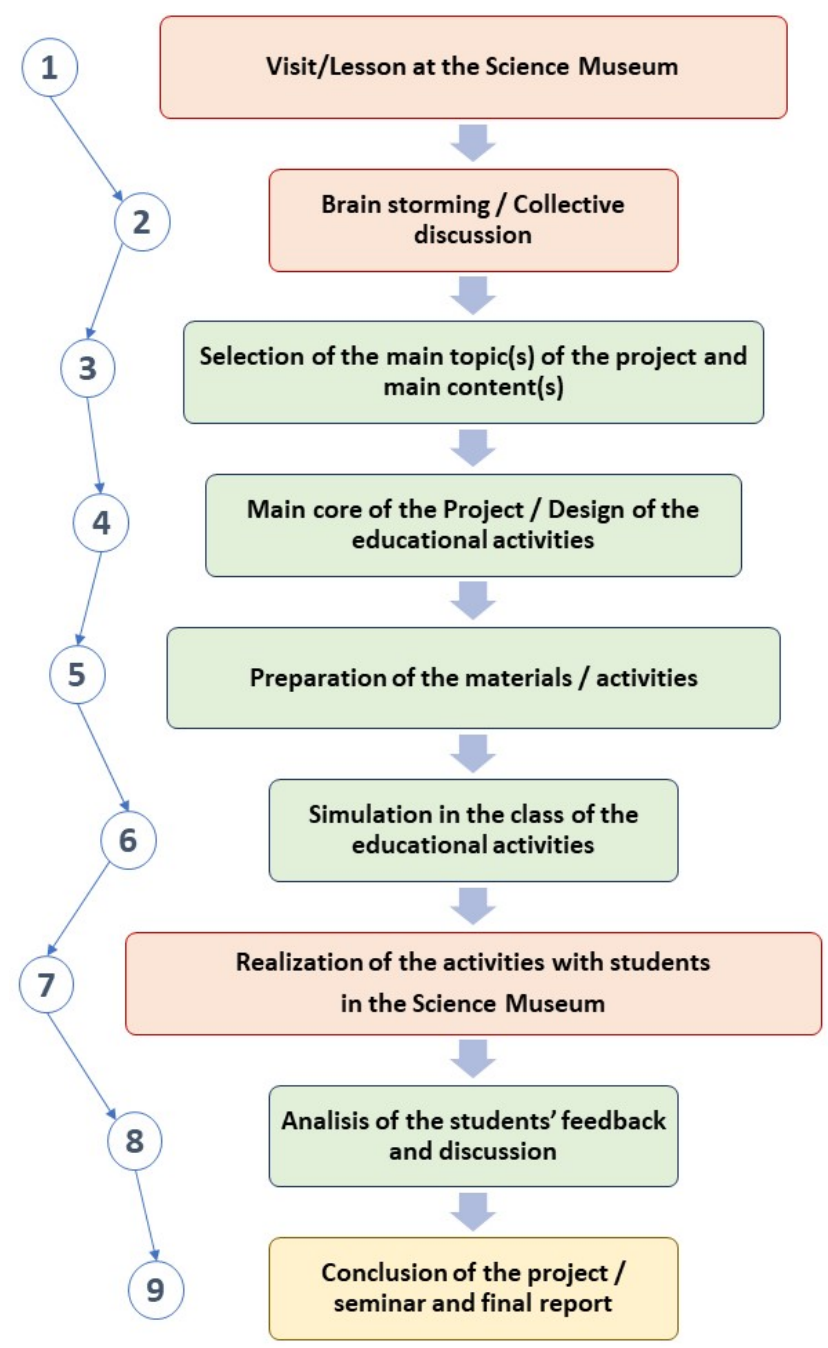

Figure 2. Scheme of the STEAM project-based learning methodology used to train future and preservice chemistry teachers during a course of 'Chemical Education' with a focus on non-formal contexts. The nine steps are described in the text. 
As reported in Table 2, some of the learning objectives of the second part of the course span in the cognitive dimension from 'understand' to 'create', without a rigid hierarchy, since most of these levels are strongly correlated. Before the third step of the STEAM project-based methodology, students are invited to divide in groups of three/four students and to decide their roles inside the group, according to the cooperative learning scheme. Typical roles are: materials manager/recorder, reporter/communicator, teamwork encourager/facilitator, eventual checker and eventual leader.

During the step 3 (see Figure 2), each group chooses a chemistry-related topic connected with a collection or a section of the science museum, a museum exposition or a historical object of the scientific collection. Based on this choice, each group plans a laboratorial activity (step 4 in Figure 2), following a hierarchic scheme of educational design (see Table 3). Steps 3 and 4 are very challenging for several reasons: students are supposed to link their chemistry knowledges with their personal experiences. At the same time, students are invited to use their creativity following the 'inspiration' get from the visit at the science museum. As evidenced in Table 2, students are also required to search in the literature and select within the materials provided by the teacher, experiences and activities as a starting point for their project. The design of the laboratorial activity (step 4 in Figure 2) is the core of the project and it needs students to be available for extra-time meetings with the members of the group and/or with the teacher.

As it will be discussed in the case study described in Section 4, the main role of the course's teacher is to facilitate the students in their projects, give additional information and help them during the design of the activities, support them in case of problems or doubts concerning the selection of ideas and choice of type of teaching strategies. Once the project is planned and the scheme of each activity (in particular laboratorial ones) is defined, each group starts preparing the materials following their project scheme (see Table 3): reagents, instruments, equipment, glassware or plastic analogous, posters, colors and all kind of materials they need. The preparation of all materials represents the step 5 of the STEAM project-based learning methodology, which is followed by the simulation of the laboratorial or other activities during a class lesson (step 6 in Figure 2).

Step 6 is very useful for pre-service chemistry teachers, since they can be more aware about the practical aspects, eventual limitations and problems, and about the timing of the activities. A selection of photos with undergraduate students engaged during steps 4, 5 and 6 in different academic years is reported in Figure 3. During COVID-19 pandemic, most of the activities were performed in remote learning modalities: lessons and cooperative learning activities were performed thought the Moodle platform in distance mode [99]. In this case, the STEAM project-based learning activities had the aim to produce educational videos and interactive web-pages that were included in the Open-Day program of the Department of Chemistry and Industrial Chemistry during 'BRIGHT 2020' [96,97] and 'BRIGHT 2021' [100] events. As shown in Figure 3e,f, the preparation of videos showing interactive laboratorial activities and explaining some chemical reactions related to specific topics ('The Chemistry of Colors' or 'The Chemical Gardens') was performed in a research lab by small groups of students, in compliance with the COVID-19 regulations. 
Table 3. General Scheme used by Pre-service Chemistry Teachers to plan The Activities and Laboratories of Their Project.

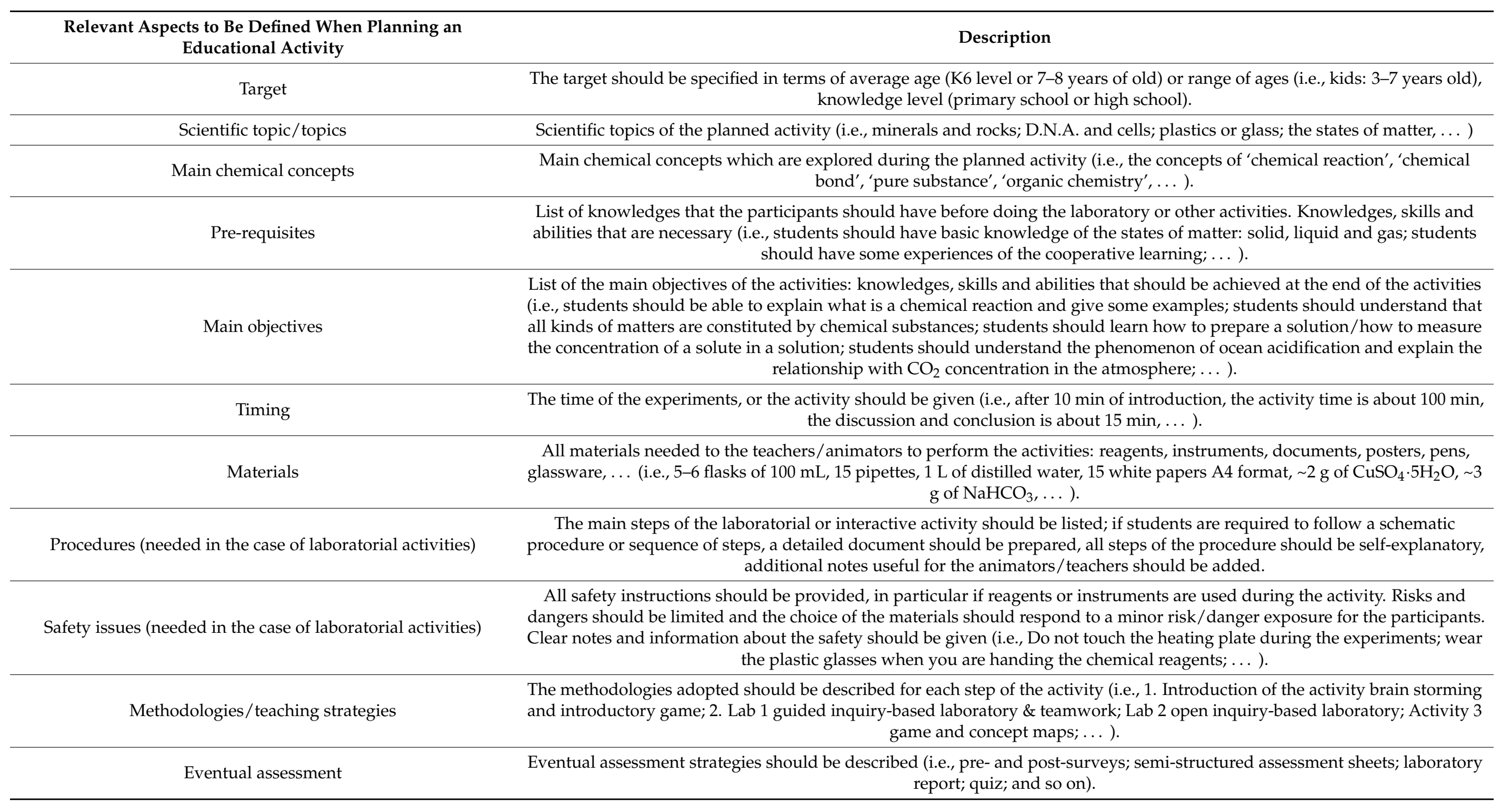



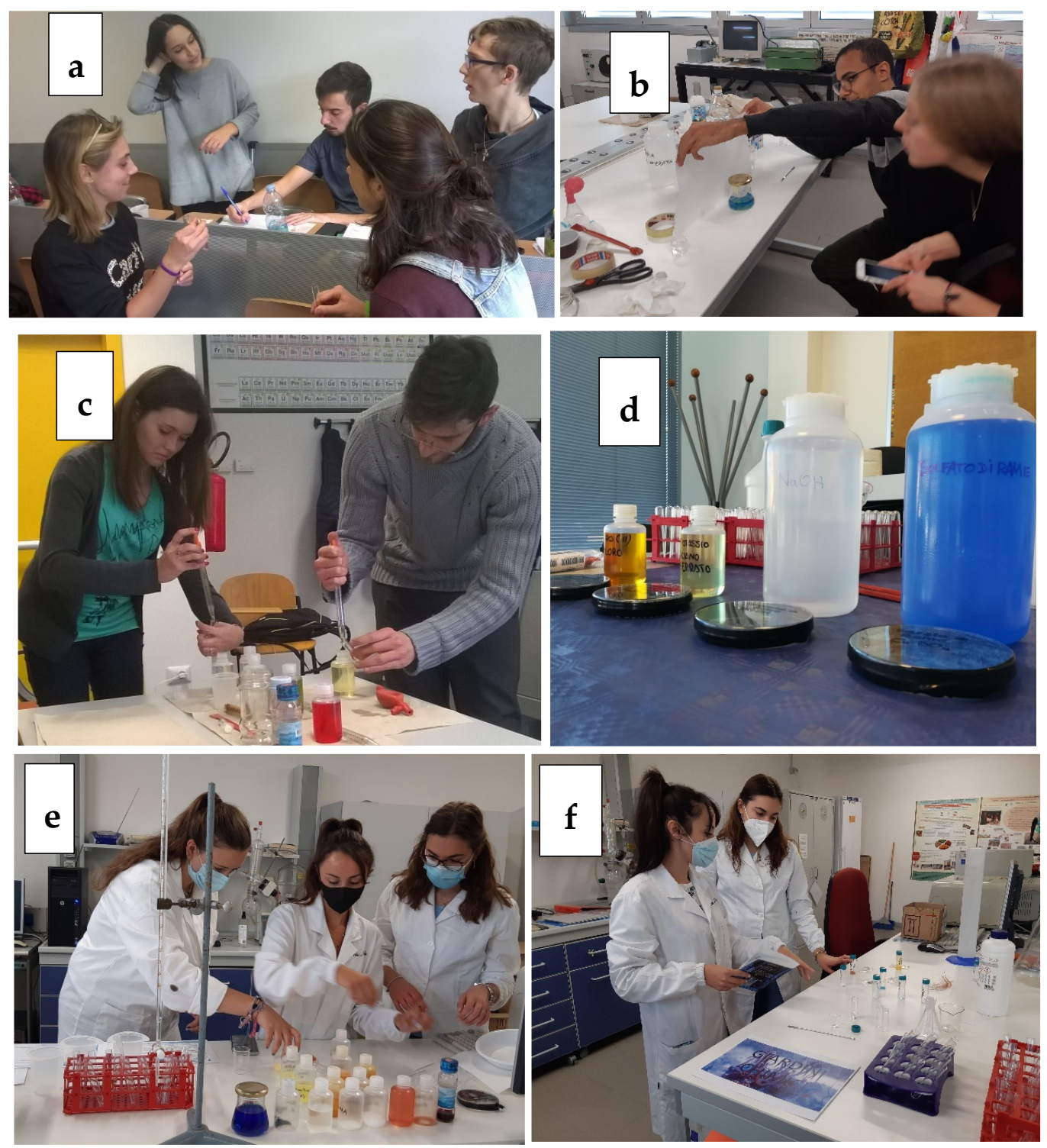

Figure 3. Photos regarding the steps (4), (5) and (6) of the STEAM project-based learning methodology (see Figure 2). Top to bottom: design of the educational activities with the cooperative learning approach (a); preparation of the materials and simulation of the laboratorial activities $(\mathbf{b}-\mathbf{d})$; preparation of the materials for the production of videos and remote interactive laboratories during COVID-19 pandemic $(\mathbf{e}, \mathbf{f})$.

After the simulation of the activities, students have usually the opportunity to perform their projects and to be actively involved in educational laboratories for kids, primary, intermediate or high school students (step 7 in Figure 2). From 2014 to 2019, most of the groups of students who participated in the project had several possibilities: some of them performed their projects at school, from primary to high schools (see Table 4), most of them were involved in the educational activities and laboratories carried out at the Science Museum "MuSNa" in Rosignano Marittimo (LI, Italy) [93] (i.e., a case study is reported in Section 4) [101] or at the University during the Open Days organized in occasion of the 'European Night of the Researchers' ('BRIGHT' project) [27,31] and in one case (2016-2017) a project was presented during the National Science Festival in Genova (Italy) [15,30] (see Table 4). In almost all cases, the carrying out of the activities was preceded by the preparation of pre- and post- questionnaires for the participants to the laboratory, as it will be shown in the case study reported in Section 4. Among the learning objectives of the STEAM project-based learning activity (see Table 2), the analysis of the pre- and 
post-surveys and the evaluation of the critical aspects concerning the experimental and practical activities from the step of simulation (step 6) to the step of carrying out (step 7) of the activities belong to higher order thinking skills ('analysis' and 'evaluation' cognitive dimension objectives).

Table 4. Number of projects designed by pre-service chemistry teachers during the various academic years and performed in different contexts, from Schools to Science Museums, Open Days and Science Festivals.

\begin{tabular}{cccccc}
\hline $\begin{array}{c}\text { Academic } \\
\text { Year }\end{array}$ & $\begin{array}{c}\text { Students' } \\
\text { Projects in } \\
\text { Primary } \\
\text { Schools }\end{array}$ & $\begin{array}{c}\text { Students' } \\
\text { Projects in } \\
\text { Intermediate } \\
\text { Schools }\end{array}$ & $\begin{array}{c}\text { Students' } \\
\text { Projects in } \\
\text { High } \\
\text { Schools }\end{array}$ & $\begin{array}{c}\text { Students' } \\
\text { Projects in a } \\
\text { Science } \\
\text { Museum }\end{array}$ & $\begin{array}{c}\text { Students' } \\
\text { Projects at } \\
\text { Open Days } \\
\text { or Science } \\
\text { Festivals }\end{array}$ \\
\hline $2013-2014$ & $3^{\prime}$ & $1^{\prime}$ & 11 & $2^{1}$ & $/$ \\
$2014-2015$ & 1 & $/$ & $/$ & 3 & $1^{2}$ \\
$2015-2016$ & 2 & 1 & $/$ & 4 & $2^{2}$ \\
$2016-2017$ & 1 & 1 & 1 & 3 & $2^{2}+1^{3}$ \\
$2017-2018$ & 2 & 1 & 1 & 3 & $2^{2}$ \\
$2018-2019$ & 1 & 1 & 15 & $2^{2}$ \\
$2019-2020$ & $/$ & 1 & $/$ & $1^{2}$ & $1^{6}$ \\
$2020-2021$ & $/$ & 1 & 1 & $1^{6}$ \\
\hline
\end{tabular}

${ }^{1}$ All projects in 2013-2014 had a common theme: 'D.N.A. and life' [6]. They were performed either at the Science Museum ('MuSNa') or at school. ${ }^{2}$ Projects carried out during the 'European Night of the Researchers' ('BRIGHT' project) $[6,27,31] .{ }^{3}$ Project done during the Science Festival in Genova $[15,30] .{ }^{4}$ Project done at the Museum during a special occasion dedicated to the Periodic Table of Elements [101]. ${ }^{5}$ A special project involving the Museum 'Galilei' in Florence [94,95] (final steps 7-9 were not done due to COVID-19). ${ }^{6}$ Projects done in virtual mode during the 'European Night of the Researchers' ('BRIGHT' project) $[96,97,100] .{ }^{7}$ Laboratorial STEM project performed in virtual mode with intermediate school' students (11-13 years old). ${ }^{8}$ Project performed last 11 of December 2021 (in presence) at the Science Museum ('MuSNa') [93].

Step 8 of the project (see Figure 2) is centered on the analysis of feedbacks, critical discussion of the students' experiences, discussion of the strengths and weaknesses of the whole educational activity. Very significant from the educational point of view is the sharing of impressions about the cooperative work inside each group. Pre-service teachers are indeed invited to comment the advantages and disadvantages of the cooperative work, and judge their own participation, involvement and activity, thus developing metacognitive skills (Table 2). During steps 8 and 9, undergraduate students are requested to explain what are the main elements of innovation of the project from the educational point of view, to indicate the limitations and critical aspects emerged during the whole activities, and, finally, to discuss the differences between the simulation and the carrying out of the activities with 'real students' or kids.

The final step of the STEAM project-based learning methodology (step 9) consists in the presentation of a final report, which is discussed during the course final exam. Preservice teachers can prepare a video, or project photos or play a game or tell a story. They can use all types of support and digital tools. The only limitation is the time: each group has 30-40 min for the presentation. During the final exam, all aspects of the project are examined and different objectives of various knowledge and cognitive dimensions are taken into account for the final exam vote.

As reported in Table 2, several aspects of the STEAM project-based learning activity are related to the use of creativity: from the design of specific interactive activities to the inclusion of games or other experiences involving communication and emotional skills, to the preparation of the materials (posters, cartoons, and so on) and the final presentation of the project. 


\subsection{Assessment and Evaluation of the Activities}

The evaluation of the STEAM project-based learning activities performed during the course of 'Chemical Education' from 2014 (2013-2014 academic year) up to know (2020-2021 academic year) was based on the analysis of some of the questions included in the final surveys introduced by the University of Pisa to evaluate the quality of the University's courses. These questions focus on the learners' perception about the topics of the course, the materials provided by the lecturers, the methodology used during the course, the eventual projects proposed during the course (as in the present case). Moreover, student's motivation and interest towards the topics of the course and their judgement of the respect for gender differences during the course are evaluated, too. The case study object of Section 4 reports additional aspects useful for the evaluation of the STEAM project. In fact, ad hoc final questionnaires were provided to pre-service chemistry teachers who participated in the carrying out of the project at the Science Museum 'MuSNa'. Questions of particular interest for the present research are those related to the students' final satisfaction and judgment of the usefulness of the STEAM project-based activities for chemistry teaching. In the case study reported in the following Section, the activities carried out at the Museum were also evaluated taking into account the feedbacks of the participants to the laboratories, which were collected by using initial and final surveys prepared by the pre-service chemistry teachers during their project. Kids' and students' feedbacks were useful to evaluate their engagement in the laboratorial activities and some specific learning outcomes.

\section{A Case Study of the STEAM Project-Based Learning Method with Pre-Service Chemistry Teachers}

\subsection{From the Visit to the Museum to the Design of the Activities}

Most of the students who attended the course in the academic year 2018-2019 (21 of 25 students, as reported in Table 1) participated in the visit at the Science Museum 'MuSNa' [93] in Rosignano Marittimo planned on the 4 October 2018. The visit (step 1) was divided in two parts: the first part (about $30 \mathrm{~min}$ ) was held in the Auditorium used for pre-service teachers' scientific animators' training courses. Here, the students were introduced to non-formal, formal and informal learning and life-long learning. The second part of the visit at the Museum started with an inspiring question: "Where is Chemistry in the Natural Science Museum?" Students were divided in four groups according to the informal cooperative learning method [102], introduced to pre-service chemistry teachers in a previous lesson of the course. Additional information was given to each group, explaining the roles of group members according to the cooperative learning strategy, the 'incipit' of the activity, showing what each group was expected to do during and after the visit, and some 'notes' useful to start planning the activity (see Figure 4).

During the second part of the activity (about $1 \mathrm{~h}$ and half), a visit was performed with the guide of volunteers of the museum to the scientific collections and museum areas: the museum library, the laboratories, the scientific collections 'Minerals and rocks', 'Mycology', 'Marine biology', 'The evolution of life' and 'Zoology' (see Figure 5). 


\section{«WHERE IS CHEMISTRY IN THE NATURAL SCIENCE MUSEUM?»}
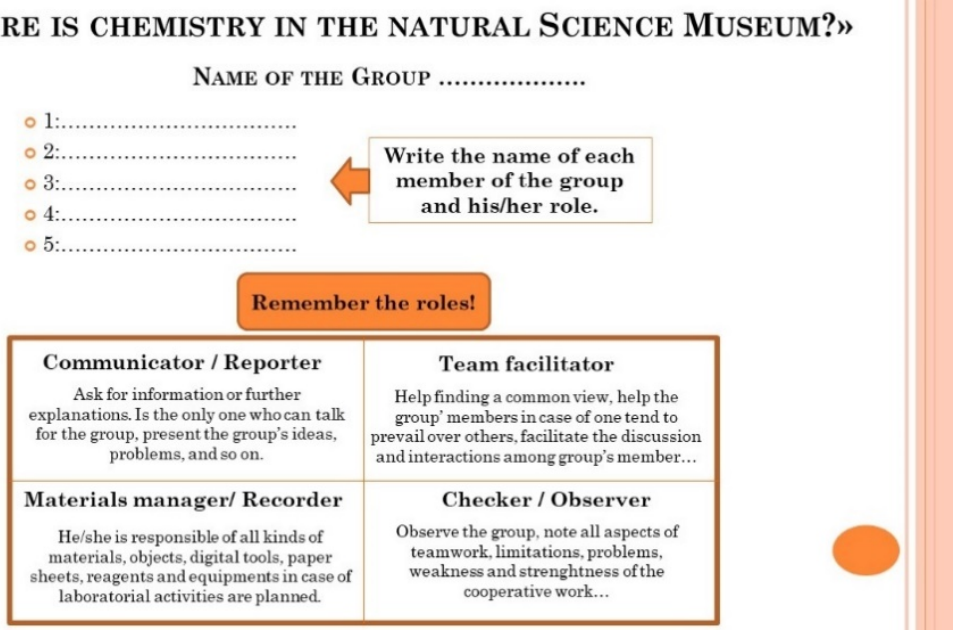

(a)

\section{«WHERE IS CHEMISTRY IN THE NATURAL SCIENCE MUSEUM?»}

\section{$\circ$ INCIPIT:}

- Imagine to be part of a group of museum animators. The science museum is planning to organize an Open Day dedicated to the Chemical Science. The museum educational manager involves all animator in the plannig of the activities. Even though the science museum is a historical natural museum, the context around the museum has several aspects related to Chemistry!

- Consider that the museum is usually visited by families during the weekend and students from primary, intermediate and high schools. During the Open Day, the idea is to organize several activities for different targets to be host in the various rooms and spaces of the museum.

- There are no limitations to the kind of activity: games, interactive activities, laboratorial activities, and so on

An important aspect during the design of the activity: a topic or a concept of chemistry should be at the center of the planned activities. The chosen topic/theme/concept of chemistry should be related to the museum room and to the scientific collection where the activity will be realized.

(b)

\section{«WHERE IS CHEMISTRY IN THE NATURAL SCIENCE MUSEUM?»}

\section{○ NOTES}

(When thinking to the activity to be planned, take into account of the following questions):

- What is the area/room/scientific collection of the Museum related to your activity?

-Who is the target of the activity? Kids, family, high school students..

- What are the chemical concepts related to the activity? What is the main topic of the activity?

- What kind of activity have you in mind? A game, a laboratorial activity, a video, an interactive lesson...

- What are the main objectives of the activities? Think in particular to eventual knowledge objectives, emotional or motivational objectives, others.

-What are the preknowledges related to chemistry and the prerequisites needed to participate to the activity?

- When planning the activities, think to the materials, equipments and instruments needed to realize them!

(c)

Figure 4. Some of the materials and information given to the pre-service chemistry teachers at the museum before visiting the Museum. These materials contain: (a) some indications how to organize the groups; (b) the 'incipit' of the activity; (c) some 'notes' to be used to design the activities. Note that this material was translated from the origin in Italian. 

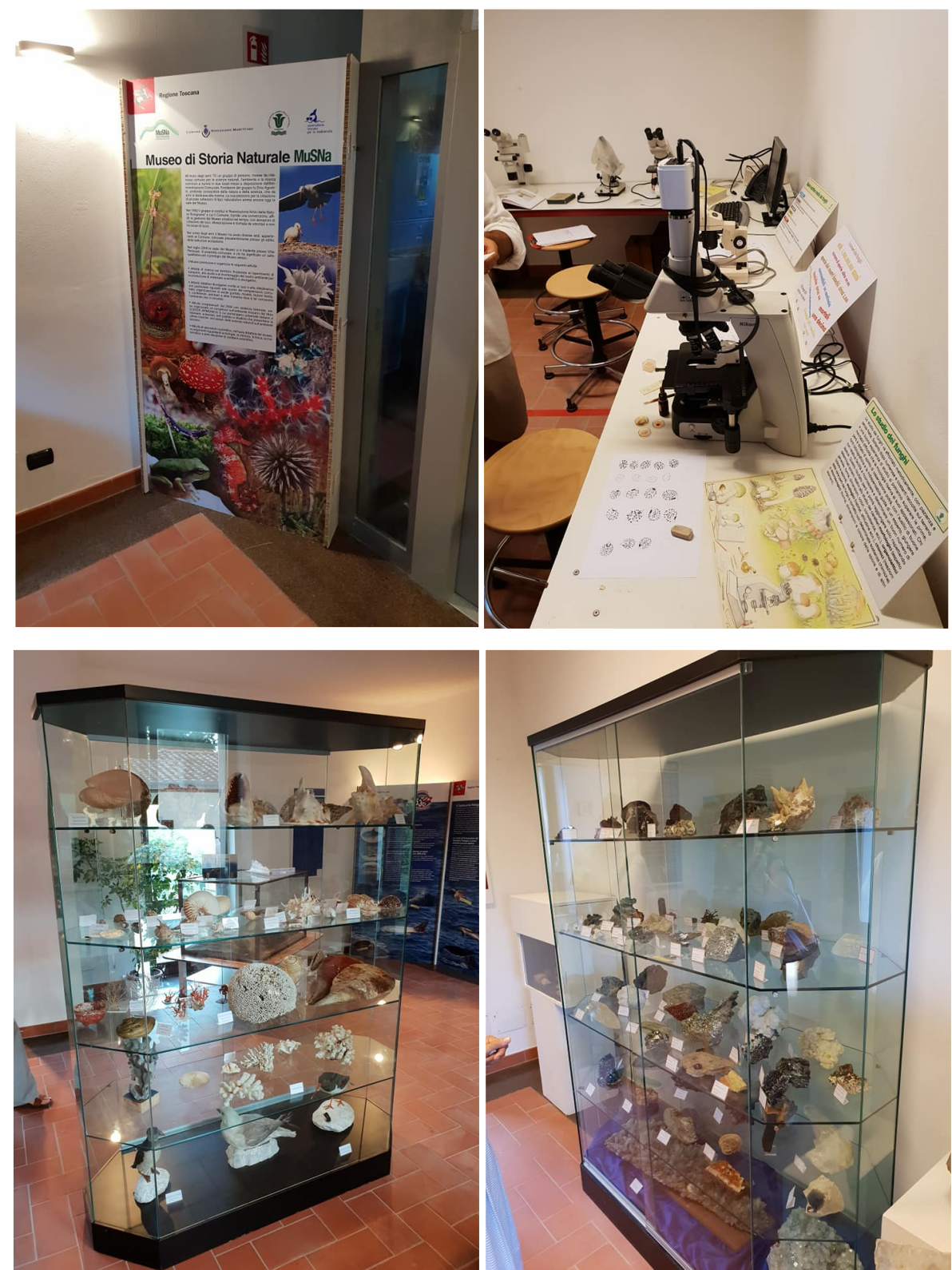

Figure 5. Photos of some rooms and scientific collections of the Science Museum 'MuSNa' in Rosignano Marittimo (LI, Italy) [93].

At the end of the visit, a collective discussion (step 2) was performed following these 'guided questions':

- How do you like the laboratorial and educational areas, such as the laboratories, present in the museum?

- What do you think about the educational activities organized at the Science Museum?

- Did you expect such variety and richness of activities performed at the Museum with the schools?

- This museum does not contain a specific section dedicated to chemistry, however, do you think is there anything to be related to chemistry?

- Is there an object, museum find, historical instrument, ... that impressed you more than others, that you would link to some chemical concepts?

The collective discussion was the input for step 3 (Figure 2): the selection of the main topics of the activities planned by each group. 
After the visit to the museum, the four groups of students continued working on the design of their project. Following the 'incipit' and 'notes' reported in Figure $4 b, c$, the four groups decided to develop their educational activities linking them to four different scientific collections: 'Marine Biology' (group 1), 'Minerals and rocks' (group 2), 'Mycology' (group 3) and 'The Evolution and life' (group 4). As reported in Section 3.3, students had some extra-time to search for ideas, documents and other materials to start designing their projects (step 4). In order to facilitate the cooperative work, after the visit of the museum, a lesson was dedicated to the presentation of each group of their preliminary ideas. The collective discussion centered on the scheme of the activities was an important part of step 4, since students could develop high order thinking, communicative and cooperative skills. Each group answered to the 'guided questions' reported in Figure 4c, and started planning their project by using the scheme reported in Table 3 for each laboratorial or interactive activity. Then, pre-service chemistry teachers started preparing the materials for their activities (step 5) and, in some cases, a simulation was performed. Students showed a high level of engagement, interest and also satisfaction in the STEAM project-learning activity, as it will be further discussed in the last section.

\subsection{From the Simulation to the Implementation of the Laboratorial Activities in the Science Museum}

Extra-time was devoted to the simulation (step 6) of some of the activities and, in particular, of the laboratorial activities. At the end of this step, the projects designed by four groups of undergraduate students were chosen and adapted for the non-formal learning context. Three of them were performed (step 7) in the Science Museum 'MuSNa' in May 2019 (see the advertisement of the laboratorial activities in Figure 6). The fourth project was presented during the 'Celebration of the Periodic Table' at the Science Museum 'MuSNa' the 1 June 2019 [101]. Even though almost all undergraduate students participated in the first steps (from 1 to 6) of the STEAM project, not all of them were available to participate at the laboratories. At the end of the course, 12 students participated in the activities at the Science Museum 'MuSNa', 5 students participated in laboratorial activities at school (primary and secondary schools), 4 students participated in the 'European Night of the Researchers' ('BRIGHT' project 2019 edition), and 2 students did not participate (note that in the 2018-2019 academic year, 23 of 25 students overcame the final course exam, as reported in Table 1).

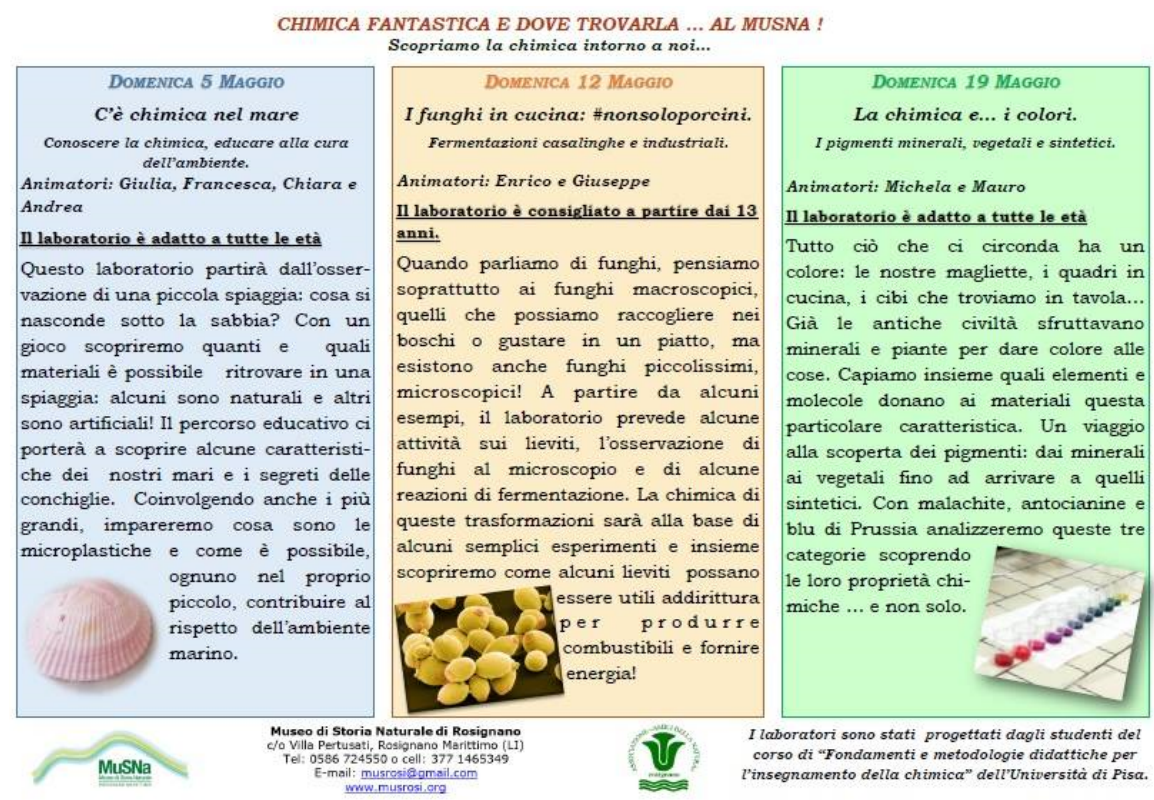

Figure 6. Advertisement of the three laboratorial activities organized at the Science Museum 'MuSNa' in Rosignano Marittimo (LI) by students attending the course in the academic year 2018-2019.

In the following, the three projects performed in the context of the Science Museum 'MuSNa' are described (see Table 5). 
Table 5. Main features of the three projects performed during the STEAM project-based learning activity and carried out at the Science Museum 'MuSNa' in May 2019.

\begin{tabular}{|c|c|c|}
\hline \multicolumn{3}{|c|}{ First Educational Project: "Chemistry and the Sea" } \\
\hline Relevant Aspects & & Description \\
\hline Target: & \multicolumn{2}{|c|}{$\begin{array}{l}\text { Children/families/adults } \\
\text { Note: activities are relatively flexible and the language can be modelled based on the target }\end{array}$} \\
\hline Scientific topic/topics: & \multicolumn{2}{|c|}{ Materials; waste; plastics and microplastics; effect of the increase of $\mathrm{CO}_{2}$ on the life in the sea; shells and corals; climate changes. } \\
\hline Main chemical concepts: & \multicolumn{2}{|c|}{ Acid-base reactions; carbonates and bicarbonates; solutions; chemical reactions; the phenomenon of the acidification of the sea. } \\
\hline Timing: & \multicolumn{2}{|c|}{$2 \mathrm{~h}$ (included time for welcome, initial and final surveys) } \\
\hline \multirow{9}{*}{ Structure of the laboratory: ${ }^{1}$} & \multirow{3}{*}{$\begin{array}{l}\text { First activity: } \\
\text { “What material last more in the sea?" (see Figure 7a) }\end{array}$} & Time: about $30 / 40 \mathrm{~min}$ \\
\hline & & Type of activity: game/interactive \\
\hline & & $\begin{array}{c}\text { Main objectives: to know and recognize different materials among waste, to understand the } \\
\text { relation between type of material and average time of degradation; to sensibilize to the } \\
\text { problem of microplastics. }\end{array}$ \\
\hline & \multirow{3}{*}{$\begin{array}{l}\text { Second activity: } \\
\text { "Put a shell in the glass and see what happens" }\end{array}$} & Time: about $15 / 20 \mathrm{~min}$ \\
\hline & & Type of activity: experiment; observation of a phenomenon. \\
\hline & & $\begin{array}{l}\text { Main objectives: to observe the reaction between carbonates (shell) and the acetic acid, to } \\
\text { understand the main features of an acid-base reaction, to understand the correlation between } \\
\text { excess of } \mathrm{CO}_{2} \text { in the atmosphere and the acidification of the sea (higher order thinking skills) }\end{array}$ \\
\hline & \multirow{3}{*}{$\begin{array}{l}\text { Third Activity: } \\
\text { "Color your shells" }\end{array}$} & Time: about $20 \mathrm{~min}$ \\
\hline & & Type of activity: simple experiment; painting and artistic creation. \\
\hline & & $\begin{array}{l}\text { Main objectives: learn a different method to get shells colored; use the creativity to realize a } \\
\text { 'souvenir of the day' } \\
\text { (see Figure } 8 \mathrm{a}-\mathrm{c} \text { ) }\end{array}$ \\
\hline
\end{tabular}


Table 5. Cont.

Second Educational Project: "Mushroom in the Kitchen, and Not only There ... "

$$
\text { Description }
$$

Relevant Aspects

Target:

Scientific topic/topics:

Main chemical concepts:

Timing

"What are the mushrooms?"

Second activity:

Structure of the laboratory: ${ }^{1}$
High school students (minimum 13 years old)

The kingdom of mushrooms; the cell structure; yeasts; the Saccharomyces cerevisiae type of yeast.

Alcoholic fermentation; chemical reactions; some reactions occurring in living organisms; representation of chemical reactions; molecular representations of organic compounds involved in the fermentations and metabolism.

Time: about $20 \mathrm{~min}$

Type of activity: lesson with projection of slides to introduce the topic

Main objectives: understand that mushrooms are present in many environments; basic knowledge of cell structure.

Time: about $30 \mathrm{~min}$

Type of activity: laboratorial activity.

Main objectives: to observe yeasts at the microscope; prepare a microscope slide and sample measure the dimension of cells.

Third activity:

"Can we do an experiment with yeasts?"

(see Figure $7 \mathrm{~b}$ )

Main objectives: to observe the reaction fermentation developed thanks to the yeasts action;
Time: about $20 / 30 \mathrm{~min}$

Type of activity: experiment; implementation and observation of the alcoholic fermentation. realize the experiment; to understand the main steps of the biodiesel (bio-alcohols) at industrial level (higher order thinking skills) 
Table 5. Cont.

Third Educational Project: "Chemistry and Colors"

\section{Relevant Aspects}

Target:

Scientific topic/topics:

Main chemical concepts Natural versus artificial chemical substances; extraction of pigments as an example of separation technique; basics of acid-base properties and reactions; concept of chemical reaction; precipitation reactions.

\section{Description}

Children/families/adults
Note: activities are relatively flexible and the language can be modelled based on the target

Timing:

rst activity:

"What are the colors used by prehistoric men?"

(see Figure 7c)

Structure of the laboratory: ${ }^{1}$

Second activity:

"Why can colors of some flowers can change from pink to violet?"

Third activity:
"How do chemists prepare synthetic pigments?"
(see Figure 7c)
$3 \mathrm{~h}$

Time: about $30 \mathrm{~min}$

Type of activity: inquiry-based laboratory.

Main objectives: to observe a selection of minerals and rocks and try to produce powders to paint as prehistoric men did; Relate the type of minerals to the colors of prehistoric paintings. Time: about $45 / 60 \mathrm{~min}$

Type of activity: laboratorial experiment; cooperative work.

Main objectives: to extract anthocyanins from flowers (such as Mallow or hydrangea flowers); extract yellow / orange pigments from turmeric roots or others; learn what are vegetable pigments; understand that anthocyanins are a kind of vegetable pigments which can change their color based on acidity; to use the extract obtained from Mallow flowers to check acid-base properties of several solutions and samples (higher order thinking skills); use vegetable pigments to color wool and cotton fibers (see Figure $8 \mathrm{~d}$ )

$$
\text { Time: about } 30 / 40 \mathrm{~min}
$$

Type of activity: experiment; precipitation reaction.

Main objectives: know some of the most used synthetic pigments in paintings; prepare and make the Prussian blue pigment; understand the features of a precipitation reaction and make some other examples; recognize among a series of pigments what are natural and what are artificial ones (higher order thinking skills). 

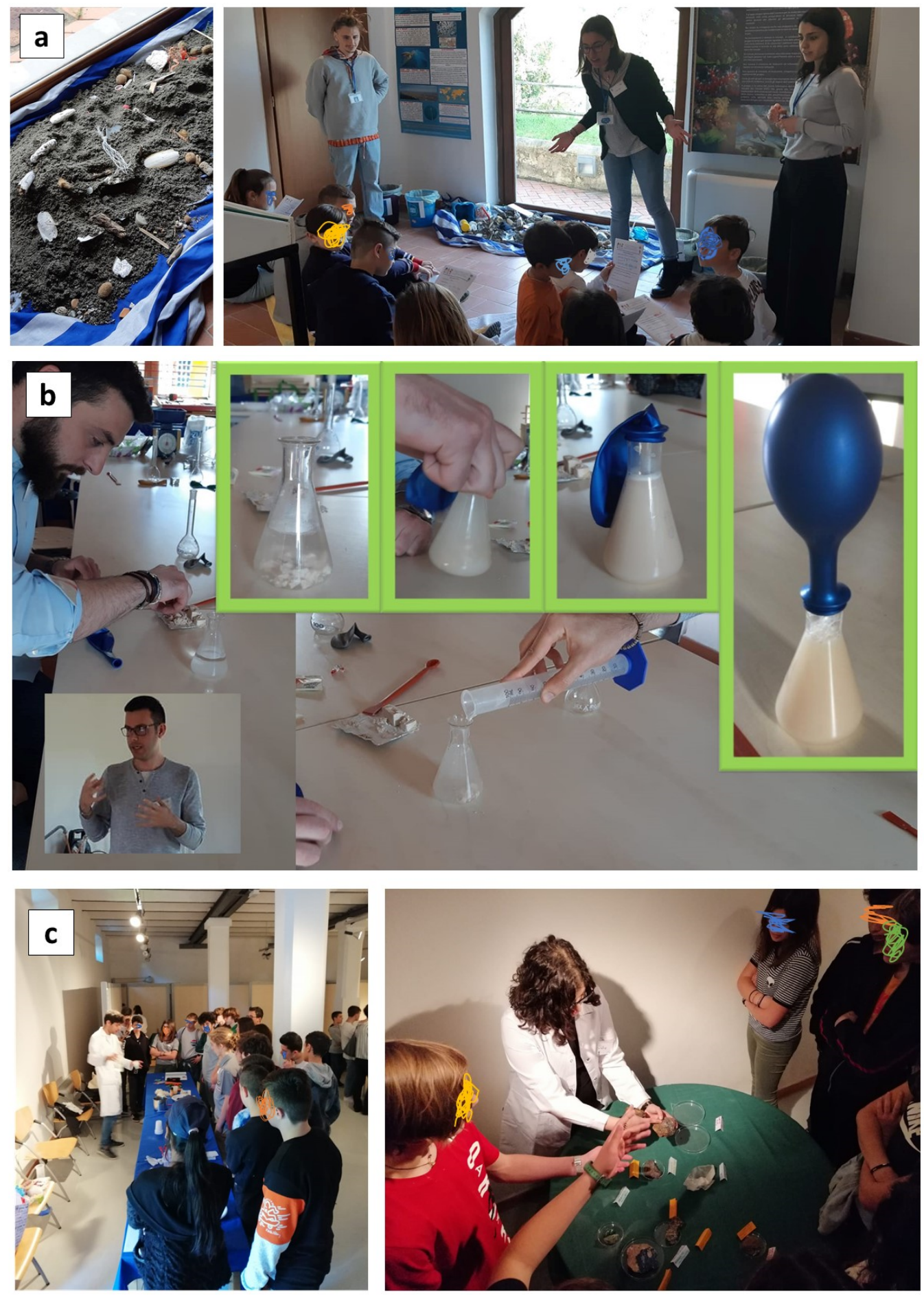

Figure 7. Photos of the three laboratories organized at the Natural Science Museum 'MuSNa' in Rosignano Marittimo (LI, Italy): (a) Activity “What material lasts more in the sea?” ('Chemistry and the Sea'); (b) snapshots from the laboratorial activity 'Fermentations and yeasts' ('Mushrooms in the kitchen, but not only there ... '); (c) Two laboratorial activities about pigments from minerals and rocks and synthetic pigments ('Chemistry and Colors'). 


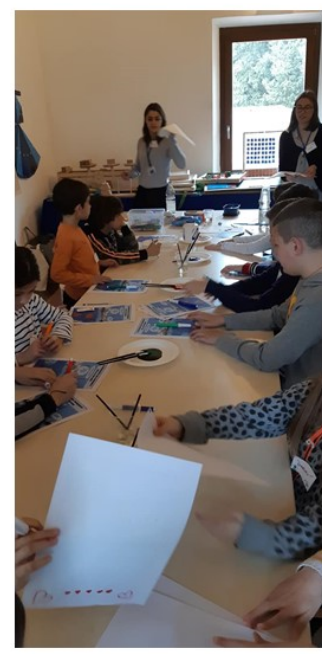

(a)

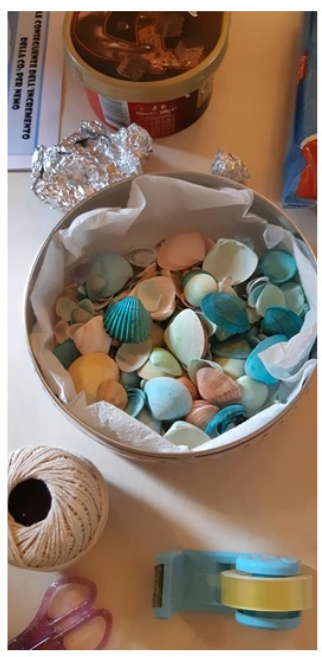

(b)

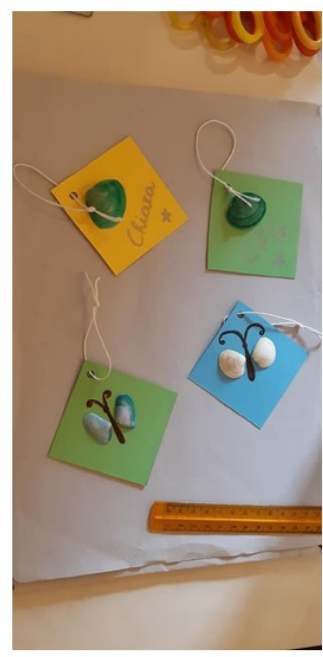

(c)

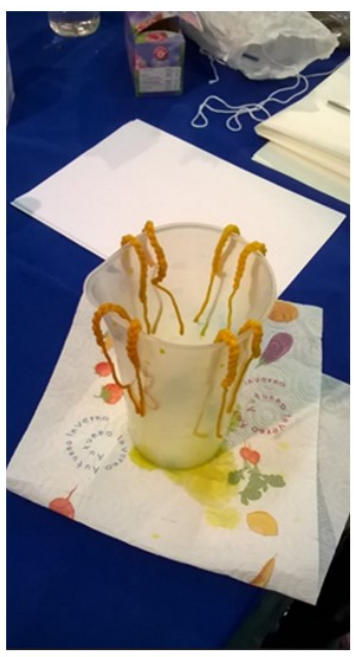

(d)

Figure 8. Snapshots at the Science Museum during creative activities: (a) Painting of the shells after treatment in weak acid solutions by using common watercolors; (b) colored shells; (c) souvenirs created by the participants of the first laboratory 'Chemistry and the sea'. (d) Painting of woolen yarns by using extracts of turmeric roots, during the third laboratory 'Chemistry and colors'.

As summarized in Table 5, the three projects were well structured. They were divided in three main activities, with a prevalence of 'inquiry-based learning' laboratories and interactive games. Among these three projects, the first and the third ones contained some creative activities, such as the painting of shells by using a particular technique based on the treatment of pristine carbonated shells in weak acid solutions in presence of watercolors (see Figure $8 \mathrm{a}-\mathrm{c}$ ) and the painting of wool and cotton fibers by using pigments extracted from vegetables, roots and flowers (see Figure $8 \mathrm{~d}$ ). Following the initial motivation question ('Where is chemistry in the natural science museum?'), pre-service chemistry teachers have used their knowledges and ideas get from the visit to the museum, to design the multidisciplinary STEAM laboratorial activities. As seen in Figure 7, the projects were host in different areas of the Science Museum 'MuSNa': the 'Marine biology', the 'Mycology', the laboratories and the 'Minerals and rocks' rooms.

\subsection{Feedback}

The three projects were performed during a series of open laboratories held at the Science Museum 'MuSNa' from the 5 to the 19 of May 2019. The participation was open and advertised through the local schools. The first and third activities had a very high participation with presence of families, adults and kids, with respect to the second one, where a small group of high school students participated, very actively, to the laboratories. The reason of such differences in terms of participation is probably related to the age limitation indicated on the advertisement ('minimum 13 years old') and on the specificity of the topic. Some data concerning the visitors of the three activities are reported in Table 6.

Initial and final surveys were prepared by the pre-service chemistry teachers for the participants of the three laboratories, in order to collect their feedbacks, but also to have information about several aspects, such as: participants' education level, previous knowledge of the topics, interest and perception towards science and chemistry, level of understanding of several concepts treated during the activity and overall activity satisfaction. In this occasion, these surveys were given only to the kids or to the students who participated in the activity, and to the adults. 
Table 6. Number of participants (adults and kids or students) participating to the three laboratories. Average age of the kids/students is also reported. Initial and final surveys were provided to kids or students who actively participated in the laboratorial and interactive activities.

\begin{tabular}{cccc}
\hline Main Outcomes & $\begin{array}{c}\text { First Laboratory } \\
\text { “Chemistry and the } \\
\text { Sea" }\end{array}$ & $\begin{array}{c}\text { Second Laboratory } \\
\text { “Mushroom in the } \\
\text { Kitchen, and Not } \\
\text { Only There .. }\end{array}$ & $\begin{array}{c}\text { Third Laboratory } \\
\text { "Chemistry and } \\
\text { Colors" }\end{array}$ \\
\hline $\begin{array}{c}\text { Total number of } \\
\text { participants }\end{array}$ & 29 & 6 & 32 \\
\hline $\begin{array}{c}\text { Number of } \\
\text { kids/students }\end{array}$ & 19 & 4 & 23 \\
\hline $\begin{array}{c}\text { Number of adults } \\
\text { Average age among } \\
\text { kids/students (years) }\end{array}$ & 10 & 2 & 7.64 \\
\hline $\begin{array}{c}\text { Number of filled } \\
\text { initial/final } \\
\text { questionnaires: }\end{array}$ & 8.95 & 18.25 & 20 \\
\hline
\end{tabular}

The initial survey of the laboratory 'Chemistry and the sea' contained some questions to check the previous knowledges of the participants on the central topic of the first activity: 'plastics and microplastics'. Among the 16 kids who participated in the laboratory and filled the questionnaires (see Table 6), 10 of them wrote that they didn't know the word 'microplastic' before coming to the Museum; 7 of them associated the word 'microplastics' to pollution; few of them gave an explanation about the origin of 'microplastics' such as: 'microplastics are in the cosmetics' (Eva, 10 years old) and 'microplastics derive from plastic bottles' (Lorenzo, 11 years old). Some of them associated the presence of microplastics to the damage of environment and sea life: 'Animals can die after eating microplastics' (Andrea, 8 years old, and Filippo, 9 years old). After the laboratorial activities, all kids knew what are microplastics and their main origins. Moreover, in the final questionnaires, 9 of 16 kids wrote some open comments and suggested solutions to the problems due to 'microplastics': 'we should produce alternative materials and not use plastics' (Marco, 11 years old), 'not use toothpaste with microplastics' (Filippo, 9 years old), 'we should differentiate the waste' (Giulia, 12 years old, and Noemi, 8 years old) and 'we should substitute plastics with other materials' (Matilde, 11 years old).

The final surveys contained several questions to evaluate the level of understanding of the chemical reaction of the second activity "Put a shell in the glass and see what happens" (namely the reaction between acetic acid and calcium carbonate immersed in water) and the understanding of the role of $\mathrm{CO}_{2}$ in the acidification of the sea. Among the results obtained, 12 of 16 kids answered correctly to the open question: 'What is the gas substance responsible of the acidification of the sea?' Kids wrote: 'carbonic oxide' or ' $\mathrm{CO}_{2}$ ' or 'carbonic anhydride' from the Italian anidride carbonica. About all kids (14 of 16) understood that shells used in the experiments are made of calcium carbonates and that the presence of acid, even weak acid, is the reason of the phenomenon of 'shells degradation and death': 'when we add acid solution to the shells, gas is produced and they break' (Andrea, 8 years old), 'shells start breaking and then they dissolve' (Noemi, 8 years old) and 'shells decompose in acid solutions' (Eva, 10 years old).

At the end of the activities, all kids gave positive feedbacks concerning their satisfaction, fun and interest about the activities. The most appreciated activity was the third one, where they could create some objects by using a painting technique learnt during the laboratory.

As previously written, the second laboratory had only six participants, two adults and four high school students who were very interested in doing experiments. In particular, they spent about one hour at the microscope in the laboratory of the museum where the 
identification of mushrooms is usually performed by using several techniques to color different parts of the mushrooms. The activity in this case was different from what planned in advance due to the small number of participants: the activities were very informal and students asked to do some different things. The pre-service chemistry teachers, who designed and prepared the activities, had the possibility to interact with high school students in a non-formal environment and to adopt a flexible and very interactive teaching method. In this laboratory, the questionnaires were not analyzed due to the low number of participants.

The third laboratory "Chemistry and Colors" had a very high participation and the average age of kids attending the laboratorial activities was between 7 and 8 years old (see Table 6). Most of the participants, except few very small kids (less than 5 years old) were at the primary school level of education with basic knowledge about natural and science phenomena. For this reason, the pre-service chemistry teachers adopted a simplified language and modified their activities in order to meet the participants' level. In this activity, 19 of 23 questionnaires were filled, giving some useful and interesting feedbacks to the undergraduate students who were the 'museum animators for a day'.

Initial questionnaires indicated that the participants were very much attracted by colors in Nature, but they didn't know the technical word 'pigment'. Moreover, most of them (18 of 19) declared to be very excited to produce a 'color' by themselves by doing an experiment. A part of the final survey aimed to check the achieved knowledge concerning the natural and synthetic pigments: 10 of 19 were able to write the name of a natural pigment and a synthetic one, 5 of 19 wrote the name of a natural pigment (i.e., chlorophyll). Concerning the main chemical concepts involved in the educational sequence, participants demonstrated to have understood the meaning of 'extraction', 'solution' and 'chemical reaction'. In fact, some of the participants were able to use these words correctly when answering to the open questions: 'we have extracted a color, named anthocyanin, from red cabbage' (Sofia, 9 years old), 'I liked to mix two solutions, yellow and orange, to form the Prussian blue' (Benjamin, 7 years old), 'I liked very much to learn how to extract pigments' (Alessio, 10 years old).

At the end of the activity, participants wrote that the most fascinating and exciting aspects of the laboratorial activities were the production of Prussian blue (12 of 19) and the extraction of natural pigments and coloring of wool and cotton fibers and tissues (7 of 19).

The qualitative analysis of the above questionnaires and the further discussion with undergraduate students after the implementation of the activities at the museum (step 8) was very important for them, since they could be more aware about several aspects of the course, such as the efficacy of non-formal learning environments, their role in the engagement of kids toward science and chemistry.

At the end of these activities at the science museum, a final semi-structured survey containing 4 items based on four points Likert scale (1=strongly disagree, $2=$ disagree, $3=$ agree, $4=$ =strongly agree), 2 open questions and 2 multiple choice questions (see Table 7) was given to the twelve undergraduate students, who participated as educators in the final activities at the science museum.

Concerning the first part of the survey (see Figure 9), most of preservice chemistry teachers were satisfied (or very satisfied) about the STEAM project-based learning activity $(92 \%)$, and they considered the possibility to implement their project in the museum context useful (or very useful) for their training (75\%). They judged positively (or very positive) the STEAM project-based learning activity for their understanding of several teaching methods $(83 \%)$, as well as to understand how to design an educational activity (92\%). 
Table 7. Final survey provided to pre-service chemistry teachers after the implementation of the laboratorial activities at the science museum.

\begin{tabular}{|c|c|c|c|c|c|}
\hline Questions: & \multicolumn{5}{|c|}{$\begin{array}{c}\text { Select the Appropriate Answer According to the Likert Scale } \\
\text { (1 = Strongly Disagree, } 2 \text { = Disagree, } 3=\text { Agree, } 4=\text { Strongly Agree) }\end{array}$} \\
\hline $\begin{array}{l}\text { Are you satisfied of the STEAM } \\
\text { project-based learning activity? }\end{array}$ & 1 & 2 & 3 & \multicolumn{2}{|c|}{4} \\
\hline $\begin{array}{l}\text { Was the implementation of the } \\
\text { activities at the Science Museum } \\
\text { useful for you? }\end{array}$ & 1 & 2 & 3 & \multicolumn{2}{|c|}{4} \\
\hline $\begin{array}{l}\text { Was the project useful to } \\
\text { understand how to design a } \\
\text { learning activity? }\end{array}$ & 1 & 2 & 3 & \multicolumn{2}{|c|}{4} \\
\hline $\begin{array}{l}\text { Was the project useful to } \\
\text { understand some teaching } \\
\text { methods? }\end{array}$ & 1 & 2 & 3 & \multicolumn{2}{|c|}{4} \\
\hline Open questions: & \multicolumn{5}{|c|}{ Answer: } \\
\hline $\begin{array}{l}\text { What are the positive and } \\
\text { negative aspects of the } \\
\text { cooperative learning according to } \\
\text { your experience with your group } \\
\text { during the project? }\end{array}$ & \multicolumn{5}{|c|}{ 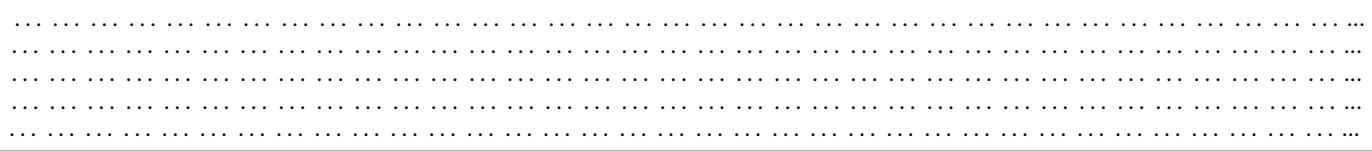 } \\
\hline $\begin{array}{l}\text { What are the positive and } \\
\text { negative aspects of the STEAM } \\
\text { project-based learning activities } \\
\text { performed at the science } \\
\text { museums? }\end{array}$ & \multicolumn{5}{|c|}{ 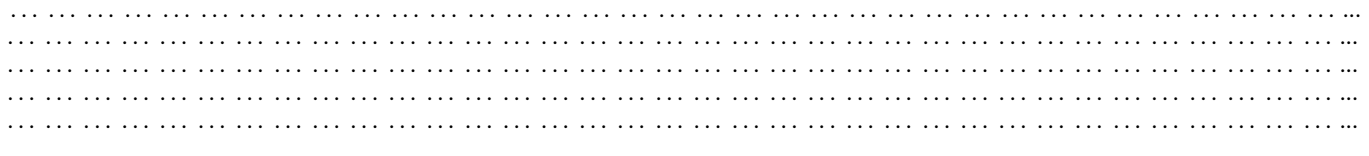 } \\
\hline Multiple choice questions & \multicolumn{5}{|c|}{ Select one or more items } \\
\hline $\begin{array}{l}\text { According to your experience, } \\
\text { what are the teaching methods } \\
\text { that you learned more during the } \\
\text { project? }\end{array}$ & $\begin{array}{l}\text { Project } \\
\text { based } \\
\text { learning }\end{array}$ & $\begin{array}{l}\text { Problem } \\
\text { solving } \\
\text { learning }\end{array}$ & $\begin{array}{l}\text { Concept } \\
\text { maps and } \\
\text { structured } \\
\text { knowledge } \\
\text { methods }\end{array}$ & $\begin{array}{l}\text { Laboratorial } \\
\text { methods }\end{array}$ & $\begin{array}{c}\text { Other } \\
\cdots \cdots \cdots \\
\cdots \cdots \cdots\end{array}$ \\
\hline $\begin{array}{l}\text { According to your experience, } \\
\text { what are the most useful aspects } \\
\text { of the project for you training as } \\
\text { future chemistry teachers? }\end{array}$ & $\begin{array}{l}\text { The possibility to design a } \\
\text { science laboratory }\end{array}$ & $\begin{array}{c}\text { The possibility to participate } \\
\text { as animators to the activities } \\
\text { with kids/students }\end{array}$ & $\begin{array}{l}\text { The possibility to experiment } \\
\text { the teaching methods and to } \\
\text { practice }\end{array}$ & $\begin{array}{l}\text { The } \\
\text { possibility } \\
\text { to do the } \\
\text { activity in a } \\
\text { non-formal } \\
\text { environ- } \\
\text { ment }\end{array}$ & $\begin{array}{c}\text { Other } \\
\ldots \ldots \ldots \ldots \\
\cdots \cdots \cdots\end{array}$ \\
\hline
\end{tabular}

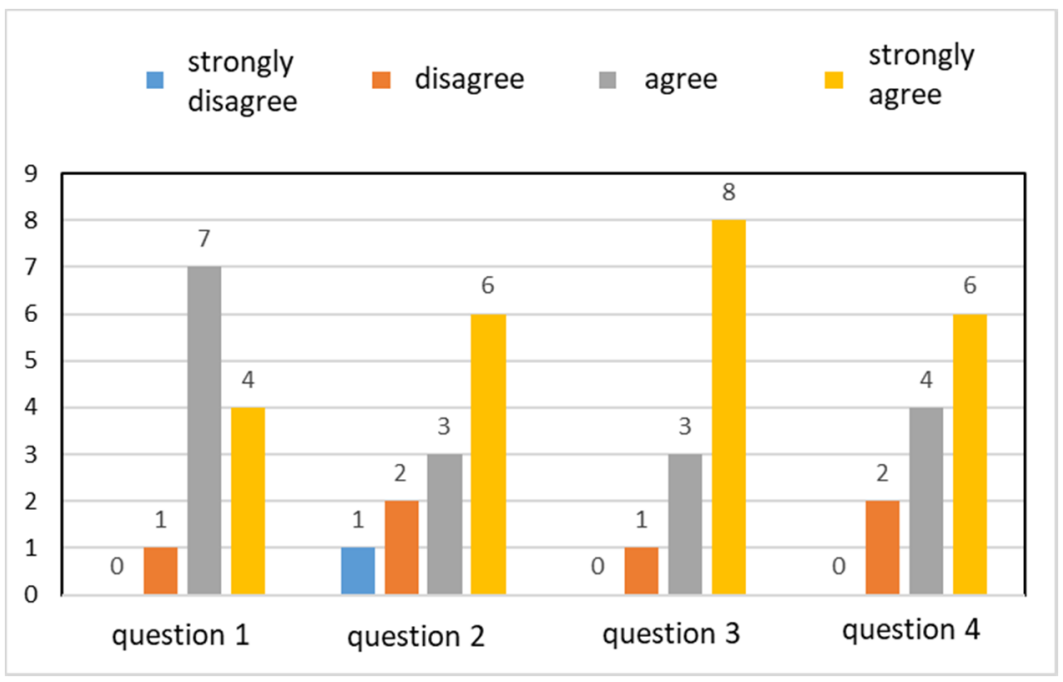

Figure 9. Evaluation of the STEAM project-based learning activities designed and performed at the Science Museum 'MuSNa' by the 12 students who participated in the academic year 2018-2019. A four points Likert scale was used to answer to the first questions of the survey, reported in Table 7. Note that the frequency of answers is reported on the vertical scale. 
From the open questions (see Table 7), undergraduate students put in evidence that they had no problems working in team by using the cooperative learning method and that the cooperative approach was useful during all steps of the STEAM project. Few students wrote that the cooperative method did not work well, since not all students participated in the various steps of the project. Among students who were satisfied or very satisfied about the carrying out of the activities at the science museum, most of them wrote that engagement of kids and students was facilitated by the non-formal context. From the answers to the open questions, the impact of the topics, such as climate changes, microplastics and environmental problems, on increasing participants' interest in science and in chemistry was evident. In this respect, the fact that the first and the third laboratories had very high participation was, according to the students, was related to the presence of interesting and very actual topics. Some students wrote that they were very much impressed about the potentiality of a science museum to teach chemistry-centered topics. Moreover, undergraduate students who answered to the multiple choice section of the survey appreciated the STEAM project-based learning activity, since it gave them the possibility to design ( 8 of 12 ) and perform (7 of 12) activities with students and kids, reaching a higher understanding and knowledge of several active teaching methods [103], such as the laboratorial methods (10 of 12), the inquiry-based learning (7 of 12), the projectbased learning (6 of 12), game and other interactive approaches (6 of 12).

\section{Discussion}

The feedbacks obtained from undergraduate students who participated in the activities at the Science Museum 'MuSNa' in 2019, reported in the previous section, can be integrated with those obtained from the analysis of the final surveys of the course of 'Chemical Education' in the last four years, namely from the inclusion of the present course among those ones of the 'PF24' training course for school teachers in Italy [38,91,92]. For the purposes of the present discussion, it is interesting to focus on six questions present in the final anonymous and voluntary questionnaire (see Section 3.2 and Table 1 for details):

1. Motivation. The question is: "Does the teacher motivate/stimulate the interest of the students toward the discipline, during the course?" Students should express their score taking into account the methodology used by the teacher, his/her behavior and the choice of the topics, and so on.

2. Clarity. The question is: "Does the teacher explain the topics of the course in a clear and understandable way?" Students should evaluate the clarity of explanation and teaching.

3. Project Evaluation. The question is: "How much do you think that the 'integrated activities' (projects, out-of-school activities, laboratories, additional training, ... ) proposed by the teacher during the course are useful for your learning?" In the case of the course of 'Chemical education', students should evaluate the STEAM project-based learning activities proposed during the course.

4. Interest. The question is: "How do you judge your interest to the topics of the course?" In particular, students should evaluate their interest in learning the active methods and strategies to teach chemistry at different school levels and in different learning context.

5. Gender Equality. The question is: "How do the teacher respect the gender differences and differences in general?" Student should express how the teacher is guarantee of the equal opportunities during the course.

6. Course Evaluation. The question is: "What is your overall judgment of the course?" Students should give a final score to the course.

To answer the above questions, students can choose among the following four-points Likert scale: $S=1$. Totally negative; $S=2$. More negative than positive; $S=3$. More positive than negative; $S=4$. Totally positive. In Figure 10, the average scores obtained from the analysis of the surveys in the last four years with respect to the above six questions are reported. The choice to select the last four academic years is related to the fact that 
since $2017 / 2018$, the course 'Chemical Education' is inserted in the program for pre-service chemistry teachers' training (PF24). These last four academic years are more uniform in terms of syllabus of the course, number of students attending the course and number of students answering to the final surveys, as reported in Table 1 and commented in Section 3.2.

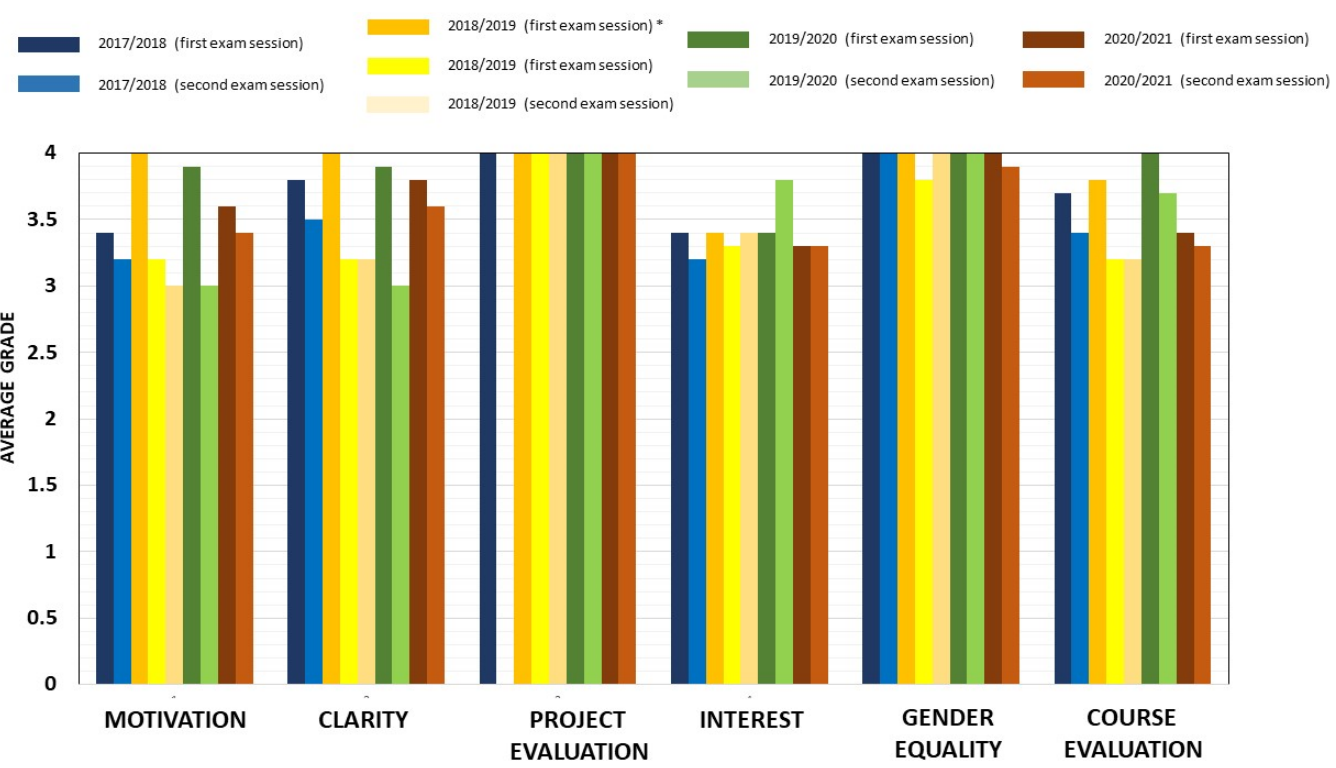

Figure 10. Students' answers to the voluntary and anonymous questionnaire concerning six aspects of the course evaluation: (1) motivation; (2) clarity; (3) project evaluation, (4) interest; (5) gender equality and (6) course evaluation. Average grades are reported, for the last four academic years: 2017/2018, 2018/2019, 2019/2020 and 2020/2021, divided in two exam sessions, as reported in the text (Section 3.2). In the case of the academic year 2018/2019, the asterisk $\left(^{*}\right)$ refer to the group of students attending the course at the last year of 'Laurea Magistrale' (degree in Chemistry).

As a general remark, in all cases the average score was higher or equal to 3, thus indicating a positive (or very positive) judgment of the students concerning the various aspects of the course. Except for the second exam session of the academic year 2017/2018, where the data were not available, in all cases the judgment of the students concerning the integrated and additional activities, namely the STEAM project-based learning activities, was the maximum, $S=4$, showing that all students who answered to the survey have express the maximum score. Similarly, the students evaluated very positively the respect toward differences and the level of guarantee of the gender equality demonstrated by the teacher. As a general trend, in almost all cases, the scores obtained at the second exam session of each academic year are slightly lower than at the first exam session. A reason could be related to the fact that students in the first exam session have a high percentage of attendance of lessons (between 90 to $100 \%$ declared by the students), while students answering to the survey in the second exam session declared or not to have attended the lessons (less than $50 \%$ of percentage) or to have attended in previous academic years without continuity. As reported previously, the academic year 2020/2021 was completely delivered in distance learning modality, however, the students' outcomes from the survey do not show significant differences with respect to previous academic years. The very positive scores concerning the motivation and interest of the students towards the main topics of the course is confirmed by the surveys given to the students who participated as educators in the laboratorial activities at the science museums.

Focusing on the undergraduate students who attended the course of 'Chemical Education' the academic year 2018/2019, whose projects carried out at the Science Museum 'MuSNa' were the object of the case study reported in Section 4, additional feedbacks are related specifically to the non-formal context. This additional survey put in evidence the 
satisfaction of most of the students concerning the possibility to implement their projects in the science museum and their positive perception of the role of non-formal contexts for their training as future chemistry teachers (see Figure 9). Most of them judged positively (or very positive) the STEAM project-based learning activity for their understanding of teaching methods $(83 \%)$, such as cooperative learning and inquiry-based learning, as well as to understand how to design an educational activity ( $92 \%$ ) by using the proposed hierarchic scheme, reported in Table 3 and discussed in this work. Among the most relevant feedbacks, undergraduate students actively involved in the project's design were very much impressed about the potentialities of laboratorial activities where chemistry is presented in connection with other sciences and with humanistic disciplines. Students who participated in the activities discussed in Section 4, for instance, appreciated very much the stimuli given by the visit to the science museum and by the museum animators during the visit to the museum collections. The possibility to develop a chemistry-centered activity in relationship with a theme or a topic stimulated by the 'Marine Biology' or the 'Mineral and rocks' collections was challenging at the beginning, but, at the end, it helped pre-service chemistry teachers to develop higher order thinking skills [69]. Moreover, they had chance to use their creativity not only during the project design, according to the STEAM teaching philosophy, but they were also able to include creative aspects in their interactive activities and laboratories [104], as shown in Section 4.2. This aspect resulted in an increased engagement and satisfaction of both undergraduate students and participants to the laboratories carried out in the non-formal contexts, from the science museum to the open days (see Table 5). Finally, it's worth noticing that those students (the majority) who decided to give the final exam of the course of 'Chemical Education' obtained high votes. As reported in Table 1, the average vote of the exam ranges between 27.75 to 30 in the eight years of experimentation, thus indicating that pre-service chemistry teachers reached a very good understanding of the main topics of the course. Students demonstrated to have developed high order thinking skills, such as the ability to critically discuss the teaching methods applied to chemistry, a good level of self-evaluation, for instance during the cooperative work, and good communication skills, as shown during the carrying out of the project at the science museum and during the final step of the STEAM project-based activity, with the presentation of their projects.

\section{Conclusions}

In the present paper, a teaching strategy adopted in the frame of a course of 'Chemical Education' at the University of Pisa (Italy) aimed to train future chemistry teachers was presented. Within this approach, called 'STEAM project-based learning' method, undergraduate students attending the course during the last eight years have experimented active teaching methods in chemistry by following the so-called STEAM teaching philosophy, by developing their projects in non-formal contexts. As reported in the paper, pre-service chemistry teachers were actively involved in the development and implementation of educational projects with kids, school students and adults. During the last eight years, in fact, more than fifty laboratorial activities and laboratories were conceived and carried out; most of them (about thirty ones) were done in out-of-school contexts, such as science museums, science festivals and during open days, as those ones organized by the University of Pisa during the 'European Night of the Researchers' ('BRIGHT' project). A case study involving undergraduate students, who attended the course of 'Chemical Education' during the academic year 2018-2019 and held the opportunity to perform their planned laboratories and interactive activities at the Science Museum 'MuSNa' in Rosignano Maritttimo (Italy) was reported and discussed. The nine steps of the 'STEAM project-based learning' method were described in details, focusing on the scheme used for the project design, the relevant educational methods adopted during the project, such as the cooperative learning work and inquiry-based learning laboratorial activities, and all aspects of the preparation of the activities and the analysis of the participants' feedbacks performed by the undergraduate students. The evaluation of the teaching methodology described in this work, performed 
by analyzing several types of feedbacks, from the final course surveys, to the main assessment's results and the specific questionnaires related to the 'STEAM project-based learning' activities, revealed that most of the objectives were successfully reached. Among them, pre-service students developed teamwork and communication skills, were highly motivated and interested to teaching and learning chemistry, and they were able to conceive and put in practice very multidisciplinary projects centered on specific chemistry topics, by using their knowledges and their creativity.

Funding: This research was funded by the National Project PRIN 2017, grant 'Material and Visual Culture of Science: a longue durée Perspective". The research activity was partially supported by the project "Realizzazione di progetti di didattica con approccio STEM in ambito museale" [(University of Pisa, 2019-2020)].

Institutional Review Board Statement: Not applicable.

Informed Consent Statement: Not applicable.

Data Availability Statement: Not applicable.

Acknowledgments: A special thanks to all students of the course "Fundaments and methodology of chemistry education" (from the academic year 2014-2015 to 2019-2020), Andrea Gori of the "Museo Galilei' in Florence (Italy). I'd like to thank volunteers and curators of MuSNa collections: Laura Leoni, Patrizia Dell'Agnello, Alessandro Lenzi, Bruno Brizzi, Franco Giorgi, Edoardo Centrella, Carla De Santi, Pierpaolo Piombanti and Carlo Baldacci for their support during students' visits at the Museum and activities with schools' students and kids.

Conflicts of Interest: The author declares no conflict of interest.

\section{References}

1. Guile, D. Learning Across Contexts. Educ. Philos. Theory 2006, 38, 251-268. [CrossRef]

2. Dohn, N.B.; Hansen, S.B.; Klausen, S.H. On the concept of context. Educ. Sci. 2018, 8, 111. [CrossRef]

3. CEDEFOP. European Guidelines for Validating non Formal and Informal Learning. Available online: https://www.cedefop. europa.eu/en/events-and-projects / projects / validation-non-formal-and-informal-learning (accessed on 4 October 2021).

4. Radovan, M. Validation of Non-Formal and Informal Learning: International Comparison. In From Formal to Non-Formal: Education, Learning and Knowledge; Žagar, I., Kelava, P., Eds.; Cambridge Scholars Publishing: New Castle, UK, 2014 ; pp. 171-191.

5. Panitsidou, E.; Griva, E.; Chostelidou, D. European Union Policies on Lifelong Learning: In-between Competitiveness Enhancement and Social Stability Reinforcement. Procedia Soc. Behav. Sci. 2012, 46, 548-553. [CrossRef]

6. Domenici, V. Lifelong learning. In Insegnare e Apprendere Chimica, 1st ed.; Mondadori Università: Firenze, Italy, 2018; pp. 159-168.

7. Lang, J.C. Epistemologies of situated knowledges: “Troubling" knowledge in philosophy of education. Educ. Theory 2011, 61, 75-96. [CrossRef]

8. Bateson, G. Steps to an Ecology of Mind: Collected Essays in Anthropology, Psychiatry, Evolution, and Epistemology, 1st ed.; University of Chicago Press: Chicago, IL, USA, 1972.

9. Hull, G.; Schultz, K. Literacy and learning out of school: A review of theory and research. Rev. Educ. Res. 2001, 71, 575-611. [CrossRef]

10. Christian, B.N.; Yezierski, E.J. A New Chemistry Education Research Frontier. J. Chem. Educ. 2012, 89, 1337-1339. [CrossRef]

11. Garner, N.; Siol, A.; Eilks, I. The Potential of Non-Formal Laboratory Environments for Innovating the Chemistry Curriculum and Promoting Secondary School Level Students Education for Sustainability. Sustainability 2015, 7, 1798-1818. [CrossRef]

12. Affeldt, F.; Weitz, K.; Siol, A.; Markic, S.; Eilks, I. A Non-Formal Student Laboratory as a Place for Innovation in Education for Sustainability for All Students. Educ. Sci. 2015, 5, 238-254. [CrossRef]

13. Affeldt, F.; Tolppanen, S.; Aksela, M.; Eilks, I. The potential of the non-formal educational sector for supporting chemistry learning and sustainability education for all students a joint perspective from two cases in Finland and Germany. Chem. Educ. Res. Pract. 2017, 18, 13-25. [CrossRef]

14. Affeldt, A.; Siol, A.; Markic, S.; Eilks, I. Differentiation in experimental work in non-formal learning environments. CHEMKON 2018, 25, 255-262. [CrossRef]

15. Domenici, V.; Tortorella, S.; Zanelli, A. Chemistry Beyond the Book: Open Learning and Activities in Non-Formal Environments to Inspire Passion and Curiosity. Substantia 2019, 3, 39-47.

16. Guerra, A.C.O. The Laboratory of Didactics of Chemistry (LaDQuim): A non-Formal Space of the Institute of Chemistry of the Federal University of Rio de Janeiro for the Promotion of Scientific Literacy and Citizenship. Rev. Virtual De Quim. 2015, 7, 903-914. [CrossRef]

17. Ballard, J.; Forman, J.E. Education, outreach and the OPCW: Growing partnerships for a global ban. Pure App. Chem. 2017, 89, 189-195. [CrossRef] 
18. Long, G.L.; Bailey, C.A.; Bunn, B.B.; Slebodnick, C.; Johnson, M.R.; Derozier, S. Chemistry Outreach Project to High Schools Using a Mobile Chemistry Laboratory, ChemKits, and Teacher Workshops. J. Chem. Edu. 2012, 89, 1249-1258. [CrossRef]

19. Pratt, J.M.; Yezierski, E.J. College Students Teaching Chemistry through Outreach: Conceptual Understanding of the Elephant Toothpaste Reaction and Making Liquid Nitrogen Ice Cream. J. Chem. Edu. 2018, 95, 2091-2102. [CrossRef]

20. Gonzalez, H.; Kuenzi, J. Science, Technology, Engineering, and Mathematics (STEM) Education: A Primer. Available online: https:/ /sgp.fas.org/crs/misc/R42642.pdf (accessed on 15 October 2021).

21. Gilbert, G.L. Role of Science Museums in Chemical Education. In Abstracts of Papers of the American Chemical Society; American Chemical Society: Washington, WA, USA, 1977; Volume 174, p. 27.

22. Domenici, V. The role of chemistry museums in chemical education for students and the general public a case study from Italy. $J$. Chem. Educ. 2008, 85, 1365-1367. [CrossRef]

23. Mori, R.C.; Kasseboehmer, A.C. Strategies for including science museums into supervised chemistry teacher internships. Quim. Nova 2019, 42, 803-811.

24. Schiffer, J.M.; Lyman, J.; Byrd, D.; Silverstein, H.; Halls, M.D. Microplastics Outreach Program: A Systems-Thinking Approach To Teach High School Students about the Chemistry and Impacts of Plastics. J. Chem. Edu. 2020, 97, 137-142. [CrossRef]

25. DeKorver, B.K.; Choi, M.; Towns, M. Exploration of a Method To Assess Children's Understandings of a Phenomenon after Viewing a Demonstration Show. J. Chem. Educ. 2017, 94, 149-156. [CrossRef]

26. Falk, J.H.; Dierking, L.D. Learning from Museums: Visitor Experiences and the Making of Meaning, 1st ed.; Alta Mira Press: Walnut Creek, CA, USA, 2000.

27. Campanella, L.; Domenici, V. La Chimica nei Musei Scientifici e i Musei di Chimica, 1st ed.; Domenici, V., Campanella, L., Eds.; Casa Editrice La Sapienza: Roma, Italy, 2014.

28. Blatti, J.L.; Garcia, J.; Cave, D.; Monge, F.; Cuccinello, A.; Portillo, J.; Juarez, B.; Chan, E.; Schwebel, F. Systems Thinking in Science Education and Outreach toward a Sustainable Future. J. Chem. Educ. 2019, 96, 2852-2862. [CrossRef]

29. Koehler, B.G.; Park, L.Y.; Kaplan, L.J. Science for kids Outreach Programs: College students teaching science to Elementary School Students and their parents. J. Chem. Educ. 1999, 76, 1505-1509. [CrossRef]

30. Domenici, V.; Dierking, I. Science for the small and the tall, the young and the old. Liq. Cryst. Today 2018, 27, 2-6. [CrossRef]

31. Domenici, V. Activity for kids about Food Chemistry at Bright 2015. La Chim. Nella Sc. 2016, 4, 49-56.

32. Luzzi, E.; Ambrogi, V.; Filippone, G.; Liguori, B.; De Luna, M.S.; Aprea, P. Increasing Awareness of Materials and the Environment: Hands-On Outreach Activity Presenting Water Purification Materials and Concepts. J. Chem. Educ. 2021, 98, 1296-1301. [CrossRef]

33. Mehlich, J.; Moser, F. Van Tiggelen, B.; Campanella, L.; Hopf, H. The Ethical and Social Dimensions of Chemistry: Reflections, Considerations, and Clarifications. Chem. A Eur. J. 2017, 23, 1210-1218. [CrossRef] [PubMed]

34. Explorations of Everyday Chemical Compounds. Natural vs. Man-Made Chemicals Dispelling Misconceptions. Available online: https:/ / www.compoundchem.com/2014/05/19/natural-vs-man-made-chemicals-dispelling-misconceptions / (accessed on 15 October 2021).

35. Royal Society of Chemistry. Public Attitude to Chemistry. Available online: https://www.rsc.org/campaigning-outreach/ campaigning/public-attitudes-chemistry (accessed on 15 October 2021).

36. Chiocca, G. A study of the perception of chemistry in young generations and of their chemical/sicentific knowledge. Master's Thesis, University of Pisa, Pisa, Italy, 2015.

37. Van Driel, J.H.; de Jong, O. Empowering Chemistry teachers' learning: Practices and new challenges. In Chemistry Education. Best Practices, Opportunities and Trends, 1st ed.; Garcia-Martinez, J., Serrano-Torregrosa, E., Eds.; Wiley-VCH Publisher: Weinheim, Germany, 2015.

38. Università di Pisa. Fondamenti E Metodologie Didattiche Per L'Insegnamento Della Chimica Valentina Domenici. Available online: https:/ / esami.unipi.it/esami2/programma.php?c=38566 (accessed on 15 October 2021).

39. Aguilera, D.; Ortiz-Revilla, J. STEM vs. STEAM Education and Student Creativity: A Systematic Literature Review. Edu. Sci. 2021, 11, 331. [CrossRef]

40. Josephsen, J.; Hvidt, S. Experimental Experience Through Project-based Learning. In Chemistry Education. Best Practices, Opportunities and Trends, 1st ed.; Garcia-Martinez, J., Serrano-Torregrosa, E., Eds.; Wiley-VCH Publisher: Weinheim, Germany, 2015.

41. Domenici, V. Distance Education in Chemistry during the Epidemic COVID-19. Substantia 2020, 4, 961.

42. Salta, K.; Paschalidou, K.; Tsetseri, M.; Koulougliotis, D. Shift From a Traditional to a Distance Learning Environment during the COVID-19 Pandemic University Students' Engagement and Interactions. Sci. Edu. 2021, 8, 1-30.

43. Marchak, D.; Shvarts-Serebro, I.; Blonder, R. Teaching Chemistry by a Creative Approach: Adapting a Teachers' Course for Active Remote Learning. J. Chem. Educ. 2021, 98, 2809-2819. [CrossRef]

44. Domenici, V. A Course of History of Chemistry and Chemical Education Completely Delivered in Distance Education Mode during Epidemic COVID-19. J. Chem. Educ. 2020, 97, 2905-2908. [CrossRef]

45. Castellanos, J.L.G. Chemistry in Our Community: Strategies and Logistics Implemented to Provide Hands-On Activities to K-12 Students, Teachers, and Families. J. Chem. Educ. 2020, 97, 1266-1274. [CrossRef]

46. EuChemS Historical Landmarks. Available online: https://www.euchems.eu/awards/euchems-historical-landmarks/ (accessed on 20 December 2021).

47. Bud, R. History of Science and the Science Museum. Br. J. Hist. Sci. 1997, 30, 47-50. [CrossRef] 
48. Badea, E. Chemistry for cultural heritage: Connecting past and future. Herit. Sci. 2019, 7, 99. [CrossRef]

49. Catalyst Science Discovery Centre. Available online: https://www.catalyst.org.uk/ (accessed on 17 October 2021).

50. The Chemistry tour at the Science Museum of London. Available online: https://blog.sciencemuseum.org.uk/the-chemistrytour / (accessed on 17 October 2021).

51. Talanquer, V. Chemistry education: Ten facets to shape us. J. Chem. Educ. 2013, 90, 832-838. [CrossRef]

52. Griffin, J. Research in students and museums: Looking more closely at the students in school groups. Sci. Educ. 2004, 81, 59-70. [CrossRef]

53. Rennie, L.J. Measuring affective outcomes from a visit to a science education centre. Res. Sci. Educ. 1994, 24, 261-269.

54. Cooke, H.; Dobbs, H.L.; Haxton, K.; Parmeggiani, F.; Skerratt, G. From Nantwich to Oxygen: Public Engagement in Chemistry at a Local History Museum. J. Chem. Educ. 2021, 98, 1249-1255. [CrossRef]

55. Frank, H.; Campanella, L.; Dondi, F.; Mehlich, J.; Leitner, E.; Rossi, G.; Ioset, K.N.; Bringmann, G. Ethics, Chemistry, and Education for Sustainability. Ang. Chem. Int. Ed. 2011, 50, 8482-8490. [CrossRef] [PubMed]

56. Shah, A.M.; Wylie, C.; Gitomer, D.; Noam, G. Improving STEM program quality in out-of-school-time: Tool development and validation. Sci. Educ. 2018, 102, 238-259. [CrossRef]

57. Groshans, G.; Mikhailova, E.; Post, C.; Schlautman, M.; Carbajales-Dale, P.; Payne, K. Digital Story Map Learning for STEM Disciplines. Educ. Sci. 2019, 9, 75. [CrossRef]

58. Hoover, J.M.; Lee, J.; Hamrick, T. Community Engagement in Science Through Art (CESTA) Summer Program. J. Chem. Educ. 2020, 97, 2153-2159. [CrossRef]

59. Conradty, C.; Sotiriou, S.A.; Bogner, F.X. How Creativity in STEAM Modules Intervenes with Self-Efficacy and Motivation. Educ. Sci. 2020, 10, 70. [CrossRef]

60. Jesionkowska, J.; Wild, F.; Deval, Y. Active Learning Augmented Reality for STEAM Education-A Case Study. Educ. Sci. 2020, 10, 198. [CrossRef]

61. Conradty, C.; Bogner, F.X. From STEM to STEAM: Cracking the Code? How Creativity \& Motivation Interacts with Inquiry-based Learning. Creat. Res. J. 2019, 31, 284-295.

62. Quigley, C.F.; Herro, D. "Finding the Joy in the Unknown": Implementation of STEAM Teaching Practices in Middle School Science and Math Classrooms. J. Sci. Educ. Technol. 2016, 25, 410-426. [CrossRef]

63. Neiles, K.Y.; Bowers, G.M.; Chase, D.T.; VerMeulen, A.; Hovland, D.E.; Bresslour-Rashap, E.; Eller, L.; Koch, A.S. Teaching Collaborations and Scientific Practices through a Vertically Scaffolded Biodiesel Laboratory Experience. J. Chem. Educ. 2019, 96, 1988-1997. [CrossRef]

64. Pinger, C.W.; Geiger, M.K.; Spence, D.M. Applications of 3D-Printing for Improving Chemistry Education. J. Chem. Educ. 2020, 97, 112-117. [CrossRef]

65. Huri, N.H.D.; Karpudewan, M. Evaluating the effectiveness of Integrated STEM-lab activities in improving secondary school students' understanding of electrolysis. Chem. Educ. Res. Pract. 2019, 20, 495. [CrossRef]

66. Velasco, J.B.; Knedeisen, A.; Xue, D.; Vickrey, T.L.; Abebe, M.; Stains, M. Characterizing Instructional Practices in the Laboratory: The Laboratory Observation Protocol for Undergraduate STEM. J. Chem. Educ. 2016, 93, 1191-1203. [CrossRef]

67. Aydin-Gunbatar, S.; Tarkin-Celikkiran, A.; Kutucu, E.S.; Ekiz-Kiran, B. The influence of a design-based elective STEM course on pre-service chemistry teachers' content knowledge, STEM conceptions, and engineering views. Chem. Educ. Res. Pract. 2018, 19, 954. [CrossRef]

68. Faulconer, E.K.; Wood, B.; Griffith, J.C. Infusing Humanities in STEM Education: Student Opinions of Disciplinary Connections in an Introductory Chemistry Course. J. Sci. Educ. Technol. 2020, 29, 340-345. [CrossRef]

69. York, S.; Lavi, R.; Dori, Y.J.; Orgill, M.K. Applications of Systems Thinking in STEM Education. J. Chem. Educ. 2019, 96, $2742-2751$. [CrossRef]

70. Wenzel, T. Collaborative and Project-Based Learning in Analytical Chemistry. ACS Symp. Ser. 2007, 970, 54-68.

71. Wheeler, L.; Sturtevant, H.; Mumba, F. Exploratory Study of the Impact of a Teaching Methods Course for International Teaching Assistants in an Inquiry-Based General Chemistry Laboratory. J. Chem. Edu. 2019, 96, 2393-2402. [CrossRef]

72. Rodriguez, J.-M.G.; Hunter, K.H.; Scharlott, L.J.; Becker, N.M. A Review of Research on Process Oriented Guided Inquiry Learning: Implications for Research and Practice. J. Chem. Educ. 2020, 97, 3506-3520. [CrossRef]

73. Thomas, J.W. A Review of Research on Project-Based Learning; Autodesk Foundation: San Rafael, CA, USA, 2000.

74. Sasson, I.; Yehuda, I.; Malkinson, N. Fostering the skills of critical thinking and question-posing in a project-based learning environment. Think. Ski. Creat. 2018, 29, 203-212. [CrossRef]

75. Ballesteros, M.A.; Daza, M.A.; Valdes, J.P.; Ratkovich, N.; Reyes, L.H. Applying PBL methodologies to the chemical engineering courses: Unit operations and modeling and simulation, using a joint course project. Edu. Chem Eng. 2019, 27, 35-42. [CrossRef]

76. Ricaurte, M.; Viloria, A. Project-based learning as a strategy for multi-level training applied to undergraduate engineering students. Edu. Chem Eng. 2020, 33, 102-111. [CrossRef]

77. Eickholt, J.; Jogiparthi, V.; Seeling, P.; Hinton, Q.; Johnson, M. Supporting Project-Based Learning through Economical and Flexible Learning Spaces. Educ. Sci. 2019, 9, 212. [CrossRef]

78. Reid, N.; Shah, I. The role of laboratory work in university chemistry. Chem. Edu. Res. Pract. 2007, 8, 172-185. [CrossRef]

79. Seery, M.K.; Agustian, H.Y.; Zhang, X.C. A Framework for Learning in the Chemistry Laboratory. Isr. J. Chem. 2019, 59, 546-553. [CrossRef] 
80. Hofstein, A. The development of high-order learning skills in high school chemistry laboratory: Skills for life. In Chemistry Education. Best Practices, Opportunities and Trends, 1st ed.; Garcia-Martinez, J., Serrano-Torregrosa, E., Eds.; Wiley-VCH Publisher: Weinheim, Germany, 2015; pp. 517-538.

81. Kelley, E.W. LAB Theory, HLAB Pedagogy, and Review of Laboratory Learning in Chemistry during the COVID-19 Pandemic. J. Chem. Edu. 2021, 98, 2496-2517. [CrossRef]

82. Dunnagan, C.L.; Gallardo-Williams, M.T. Overcoming Physical Separation During COVID-19 Using Virtual Reality in Organic Chemistry Laboratories. J. Chem. Edu. 2020, 97, 3060-3063. [CrossRef]

83. Caceres-Jensen, L. Learning Reaction Kinetics through Sustainable Chemistry of Herbicides: A Case Study of Preservice Chemistry Teachers' Perceptions of Problem-Based Technology Enhanced Learning. J. Chem. Educ. 2021, 98, 1571-1582. [CrossRef]

84. Bopegedera, A.M.R.P.; Coughenour, C.L. An Interdisciplinary, Project-Based Inquiry into the Chemistry and Geology of Alkaline Surface Lake Waters in the General Chemistry Laboratory. J. Chem. Educ. 2021, 98, 1352-1360. [CrossRef]

85. Cruz-Guzmán, M.; García-Carmona, A.; Criado, A.M. Proposing Questions for Scientific Inquiry and the Selection of Science Content in Initial Elementary Education Teacher Training. Res. Sci. Educ. 2020, 50, 1689-1711. [CrossRef]

86. Boaventura, D.; Neves, A.T.; Pereira, P.C.; Caldeira, M.F.; Santos, J.; de Carvalho, A.P. Linking pre-service teachers to a research project on climate change and citizen science with primary students. In Proceedings of the 11th annual International Conference of Education, Research and Innovation, Seville, Spain, 12-14 November 2018.

87. Aydin-Gunbatar, S.; Ekiz-Kiran, B.; Selcan Oztay, E. Pre-service chemistry teachers' pedagogical content knowledge for integrated STEM development with LESMeR model. Chem. Educ. Res. Pract. 2020, 21, 1063. [CrossRef]

88. Uzuntiryaki-Kondakci, E.; Tuysuz, M.; Sarici, E.; Soysal, C.; Kilinc, S. The role of the argumentation-based laboratory on the development of pre-service chemistry teachers' argumentation skills. Int. J. Sci. Edu. 2021, 43, 30-55. [CrossRef]

89. D'eon, J.C.; Stirchak, L.T.; Brown, A.-S.; Saifuddin, Y. Project-Based Learning Experience That Uses Portable Air Sensors to Characterize Indoor and Outdoor Air Quality. J. Chem. Educ. 2021, 98, 445-453. [CrossRef]

90. Rogers, B.A.; Zhang, Y. Project-Based Experiment in a Physical Chemistry Teaching Laboratory: Ion Effects on Caffeine Partitioning Thermodynamics. J. Chem. Educ. 2020, 97, 4173-4178. [CrossRef]

91. University of Pisa. The Degree in Chemistry. Available online: https://esami.unipi.it/esami2/ects_cds.php?cds=CHI-L\&aa=2018 (accessed on 20 October 2021).

92. Gazzetta Ufficiale della Repubblica Italiana. Italian Law 107/2015 about the NEW teaching System and Enrollment Rules for Teachers: Reform of the National Education and Training System and Delegation for the Reorganization of the Current Legislative Provisions (15G00122). Available online: https:/ / www.gazzettaufficiale.it/eli/id/2015/07/15/15G00122/sg (accessed on 20 October 2021).

93. Scientific Museum "MuSNa" in Rosignano Marittimo. Available online: http:/ /www.musrosi.org/ (accessed on 20 October 2021).

94. Università di Padova. The Special Didactic Project. Available online: https://www.unipi.it/index.php/docenti2/item/20162chimica-e-chimica-industriale (accessed on 20 October 2021).

95. Museo galileo. Istituto e Museo di Storia della Scienza “Museo Galileo”. Available online: https://www.museogalileo.it/it/ (accessed on 2 October 2021).

96. University of Pisa. Project of the Dipartimento di Chimica e Chimica Industriale: Virtual activities about chemical gardens. Available online: https:/ / bright.dcci.unipi.it/latest-edition/edizione-2020/8-pagine-principali/26-giardini-chimici-2020.html (accessed on 2 October 2021).

97. University of Pisa. Fare Chimica con la luce: Introduzione. Available online: https://bright.dcci.unipi.it/chimica-luceintroduzione.html (accessed on 2 October 2021).

98. Anderson, W.L.; Krathwohl, R.D.; Airasian, W.P.; Cruikshank, A.K.; Mayer, E.R.; Pintrich, R.; Raths, J.; Wittrock, M.C. A Taxonomy for Learning, Teaching, and Assessing: A Revision of Bloom's Taxonomy of Educational Objectives, 1st ed.; Addison Wesley Longman: Boston, MA, USA, 2001.

99. University of Pisa. The e-Learning Platform of the Course in 'Chemical Education'. Available online: https://polo3.elearning. unipi.it/course/view.php?id=3166 (accessed on 28 October 2021).

100. University of Pisa. Programma. Available online: https://bright.dcci.unipi.it/programma.html (accessed on 28 October 2021).

101. Associazione Amici della Natura Rosignano. Celebriamo I 150 Anni Della Tavola Periodica. Available online: http://www. musrosi.org/?p=673 (accessed on 2 November 2021).

102. Johnson, D.W.; Johnson, R.T. Making Cooperative Learning Work. Theory Into Pract. 1999, 38, 67-73. [CrossRef]

103. Poë, J.C. Active learning pedagogies for the future of globalchemistry education. In Chemistry Education. Best Practices, Opportunities and Trends, 1st ed.; Garcia-Martinez, J., Serrano-Torregrosa, E., Eds.; Wiley-VCH Publisher: Weinheim, Germany, 2015.

104. Avargil, S.; Herscovitz, O.; Dori, Y.J. Challenges in the transition to large-scale reform in chemical education. Think. Ski. Creat. 2013, 10, 189-207. [CrossRef] 